\title{
Suspension feeders as natural sentinels of the spatial variability in food sources in an Antarctic fjord: A stable isotope approach
}

\author{
Gastón Alurralde ${ }^{\mathrm{a}, *}$, Verónica L. Fuentes ${ }^{\mathrm{b}}$, Marleen De Troch $^{\mathrm{c}}$, Marcos Tatián ${ }^{\mathrm{a}, \mathrm{d}}$ \\ ${ }^{a}$ Instituto de Diversidad y Ecología Animal (IDEA), CONICET-UNC and Facultad de Ciencias Exactas, Físicas y Naturales, Universidad Nacional de Córdoba, Córdoba, \\ Argentina \\ ${ }^{\mathrm{b}}$ Institut de Ciències del Mar (ICM-CSIC), Barcelona, Spain \\ c Ghent University, Marine Biology, Ghent, Belgium

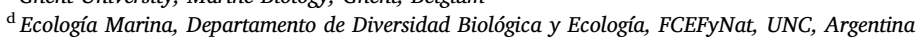

\section{A R T I C L E I N F O}

\section{Keywords:}

Western Antarctic Peninsula

Potter cove

Climate change

Glacial melting

Benthic suspension feeders

Food sources

Spatial heterogeneity

Isotopic analysis

\begin{abstract}
A B S T R A C T
We examined the effect of glacial melt-related retreat environmental conditions on the spatial heterogeneity of food sources for Antarctic nearshore marine benthic communities of Potter Cove, a representative fjord on King George Island on the West Antarctic Peninsula. Focusing on Antarctic suspension feeders, we surveyed the variation of carbon $\left(\delta^{13} \mathrm{C}\right)$ and nitrogen $\left(\delta^{15} \mathrm{~N}\right)$ stable isotopes in three different stations with contrasting characteristics in terms of glacier-sedimentary regimes and distance from the glacier. Bayesian mixing models were used to estimate the relative contribution of eight potential food sources at the study sites and to the consumers' diet. The isotopically signatures of suspension feeders displayed a broad range of assimilate available food sources with distinct contributions at each site. Overall, for most of the suspension feeders analysed, contributions of suspended particulate matter and macroalgae detritus tended to prevail over the rest of the potential food sources. Additionally, we confirm the assimilation of krill faeces by benthic organisms reinforcing its relevance as food source in nearshore Antarctic ecosystems. Mixing models corroborated the influence of glacier discharge on the spatial distribution of available food sources, since their contribution in the suspension feeders diet was different and more heterogeneous in the internal stations (ice-proximal zone) than in the external one (ice-distal zone). The analysis of isotopic signatures of primary benthic consumers (suspension feeders) indicated the spatial heterogeneity of food sources and its composition in coastal Antarctic nearshore, as consequence of the glacial influence on the local environment and hydrology.
\end{abstract}

\section{Introduction}

Where an animal gets its food and how energy (carbon) moves within and among habitat patches are key aspects to understand ecosystem functioning. According to recent Antarctic studies, nearshore benthic communities don't rely that much on seasonal phytoplankton pulses, but on multiple primary food sources (Corbisier et al., 2004; Norkko et al., 2007; Gillies et al., 2013; Pasotti et al., 2015; Alurralde et al., 2019; Zenteno et al., 2019). The existence of multiple supplies would be key for the stability of benthic communities (Lawton, 1994) in the face of ongoing coastal environmental disturbances (Gutt et al., 2015; Sahade et al., 2015), nevertheless the community structure is influenced largely by composition and amount of available energy sources (Jansen et al., 2018a,b). The focus of those studies, not always account for the complexity inherent to systems highly influenced by a wide array of abiotic factors that determine spatial and temporal variation of energy sources. Thus, the access to various energy sources might turn Antarctic nearshore benthic communities vulnerable, as the animals could be spatially segregated from the ultimate autotrophic source on which they rely (Guest et al., 2004; Zenteno et al., 2019). Environmental and physico-chemical conditions in Antarctic coastal waters are strongly shaped by glacier meltwater discharge (Gutt et al., 2015; Meredith et al., 2018), which influence photosynthetic activity (Schloss et al., 1997, 2002) and the availability of inorganic carbon and nitrogen sources (Jerosch et al., 2018). For instance, the retreat of tidewater glaciers and the ice cover in the Western Antarctic Peninsula (WAP) (Cook et al., 2005; Vaughan, 2006) have set new environmental features like summer meltwater run-off carrying high particle loads into the coastal area (Schloss et al., 2012; Bers et al., 2013; Monien et al., 2017). Variable water retention times and stratification due to the addition of summer meltwater, combined with the patchy addition of continental meltwaters and sediment plumes, may dilute the

\footnotetext{
* Corresponding author.

E-mail address: mitocondriarevelde@gmail.com (G. Alurralde).
} 


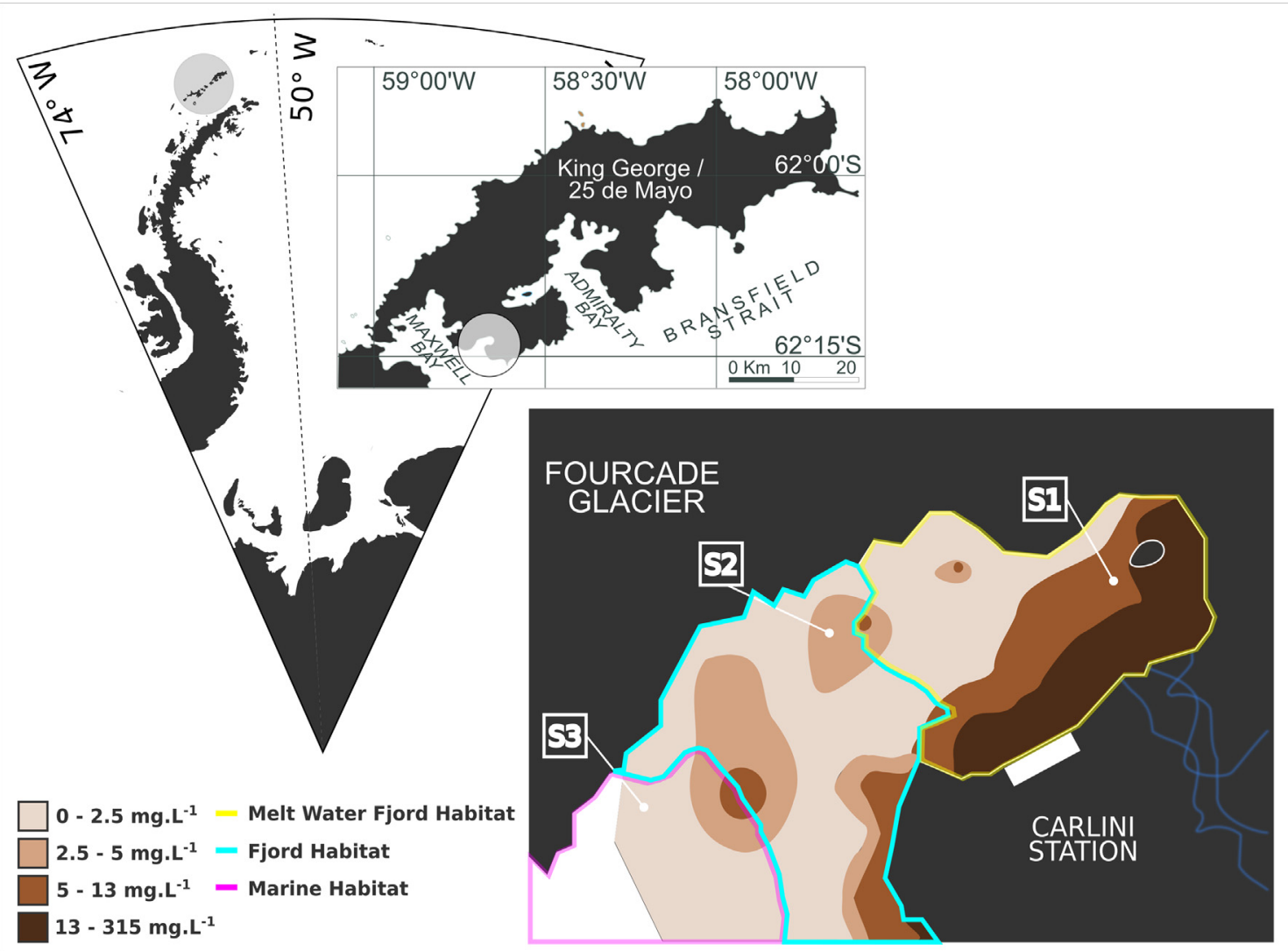

Fig. 1. Map of the study area showing the different habitats (after Jerosch et al., 2018) and sampling points at Potter Cove.

availability of food sources or at least, influence the spatial distribution of it (Corbisier et al., 2004; Norkko et al., 2007; Gillies et al., 2012). King George Island, the largest of the South Shetland Islands in the north of the WAP, is strongly affected by ice cover lost (Rückamp et al., 2011) with high glacial sediment-laden meltwater run-off, reaching the coastal areas around the island (Meredith et al., 2018). Potter Cove is a small fjord in the southwestern end of the island that opens into Maxwell Bay and it is surrounded in its northern-east part by the Fourcade Glacier. Local differences between the inner and outer part of the fjord, as well as between surface and deeper waters, have become a clear feature for spring/summer season in the last 20 years as a response to the influence of the Fourcade Glacier and wind stress (Schloss et al., 2012; Jerosch et al., 2018). These variables force the structure of the water column via stabilization (decreasing salinity) and destabilization (mixing) processes and influence suspended particulate matter (SPM) concentration in surface waters of the inner cove. Both factors seem to control phytoplankton biomass accumulation and light limitation for phytoplankton photosynthesis (Schloss et al., 1997; Schloss et al., 2002). Furthermore, it has been suggested that different glacier retreatrelated history in the inner part of the fjord, have shaped the isotopic niches of benthic fauna (Pasotti et al., 2015). The abundant and diverse benthic communities of Potter Cove (Sahade et al., 2015; Lagger et al., 2017) would therefore be supported by a diverse array of food sources (Pasotti et al., 2015; Alurralde et al., 2019). Nevertheless, producers and consumers in patches under different glacial influence (i.e. sedimentation regimes) are likely to have different food sources as a consequence of environmental heterogeneity. The benthic communities in Potter Cove are dominated by suspension feeders such as hydrozoans, corals, glass sponges and ascidians (Sahade et al., 2015). This functional group gathers a diverse array of marine heterotrophic species that feed on particles suspended in the water column (Dame et al., 2001), throughout different feeding modes (Riisgård and Larsen, 2010). Within suspension feeders, filter feeders denote a specialised set of animals that use filtering structures (e.g. mucus nets, setae, rakes) to retain particles with different efficiency depending on size and shape (Riisgård and Larsen, 2010). It is possible that the spatial variability in food sources explain the abundance and high turnover of suspension feeders species within the fjord. In order to assess food sources nourishing the benthos and to determine if melt-related retreat environmental conditions defines any spatial heterogeneity of these sources, we used carbon $\left(\delta^{13} \mathrm{C}\right)$ and nitrogen $\left(\delta^{15} \mathrm{~N}\right)$ stable isotopes analysis. We focused on Antarctic suspension feeders as a functional group but also to filter feeders as a particular group within it, because they are dominant representatives in the study site (Sahade et al., 2015; Lagger et al., 2018). Suspension feeders allow to revealing small-scale spatial isotopic variation, even within one homogeneous habitat, spread over a few hundred meters (Dubois et al., 2007; Dubois and Colombo, 2014). They are known to show no significant interannual differences and mirror well the isotopic signatures of the water column production (Mincks et al., 2008; Hyndes et al., 2013). In this work we refer to suspension feeders as animals that share the same energetic source (food), while filter feeders is limited to a sub-group of suspension feeders with specific active capture mechanisms. This study aimed at characterizing the available summer food sources for suspension/filter feeders along a glacial influence gradient in Potter Cove by assessing: (1) spatial patterns, if any, in the $\delta^{13} \mathrm{C}$ and the $\delta^{15} \mathrm{~N}$ of suspension feeders subjected to different sedimentation regimes; and (2) how these changes are linked to the relative importance of run-off inputs from melting glaciers. We assumed that suspension feeders may vary in their isotopic signatures over small scales due to the availability of different food sources amongst patches. Thus, we hypothesised that the isotopic signature of suspension feeders will vary with respect to a gradient of sediment concentration at different distances from the front of the glacier and as such be good indicators of environmental change. 
Table 1

\begin{tabular}{|c|c|c|c|}
\hline Foodsources & $\delta^{13} \mathrm{C}$ & $\delta^{15} \mathrm{~N}$ & Source \\
\hline Krill faeces & $-25.27 \pm 1.14$ & $7.61 \pm 1.47$ & This study \\
\hline Macroalgae detritus & $-26.79 \pm 1.44$ & $2.14 \pm 1.23$ & This study \\
\hline SPM & $-26.25 \pm 1.42$ & $0.53 \pm 1.65$ & This study \\
\hline Phytoplankton & $-24.32 \pm 1.23$ & $3.96 \pm 0.75$ & This study \\
\hline Sediments S $1^{(*)}$ & $-18.34 \pm 1.43$ & $3.56 \pm 0.78$ & Pasotti et al. 2015 \\
\hline Sediments S2 ${ }^{(*)}$ & $-19.77 \pm 0.89$ & $3.31 \pm 0.48$ & Pasotti et al. 2015 \\
\hline Microphytobenthos & $-13.15 \pm 0.35$ & $4.90 \pm 0.14$ & Pasotti et al. 2015 \\
\hline Macroalgae & $-25.03 \pm 5.45$ & $3.08 \pm 0.85$ & Pasotti et al. 2015 \\
\hline
\end{tabular}

(*) superficial bottom sediments

\section{Methods}

\subsection{Study site}

The study was conducted in Potter Cove $\left(62^{\circ} 14^{\prime} \mathrm{S}, 58^{\circ} 40^{\prime} \mathrm{W}\right)$, which is a shallow bay located in King George Island/25 de Mayo (South Shetland Islands). The cove (Fig. 1) covers approximately $8 \mathrm{~km}^{2}$ (Jerosch et al., 2018) with a maximum depth of $100 \mathrm{~m}$ (Wölfl et al., 2014) and is surrounded by the Fourcade Glacier in its north and east side. During the summer season, several melt water creeks inject high amounts of meltwater and sediments from the glacier (average maximum $284 \mathrm{mg} \mathrm{L}^{-1}$ ) into the cove (Monien et al., 2017). Retention of the meltwater plume within the cove by the predominant north-westerly winds enhances deposition and accumulation of sediments on the seabed. Thus, the combined environmental and hydrographic conditions, define the existence of three glacial-influenced habitats: meltwater fjord habitat, fjord and marine habitats (Jerosch et al., 2018).

\subsection{Potential organic matter sources (OMS)- food sources}

To assess the food sources (Table 1), we used SPM, plankton, macroalgae detritus and krill faeces collected during summer season of 2013-2014 (see also Alurralde et al., 2019). Samples of SPM were collected by pumping water directly from the cove. Plankton was collected by towing a net ( $63 \mu \mathrm{m}$ mesh size) horizontally in the outer part of the cove to ensure the predominance of phytoplankton in the sample, and transferring it to a $60 \mathrm{~L}$ tank with filtered $(0.1 \mu \mathrm{m})$ seawater. Macroalgae detritus was collected by sieving debris directly from the water column after stormy days that lead to resuspension of detrital beds. Detritus was dried $\left(60{ }^{\circ} \mathrm{C}\right)$, ground and sieved through a $50 \mu \mathrm{m}$ mesh before diluting them to filtered $(0.1 \mu \mathrm{m})$ seawater at a final concentration of $5 \mathrm{mg} \mathrm{L}^{-1}$. Six subsamples of $600 \mathrm{ml}$ from each source were filtered on pre-combusted and pre-weighted GF/F filter, gently rinsed with Milli-Q water and stored frozen at $-80^{\circ} \mathrm{C}$. Krill faeces were obtained from different krill incubations, where they were fed on the previously mentioned sources. Faeces were collected, gently rinsed with Milli-Q water and stored in eppendorf tubes at $-80{ }^{\circ} \mathrm{C}$. All samples were finally freeze dried $\left(\mathrm{P}=0.1 \mathrm{mbar}\right.$ and $\left.\mathrm{T}=-80^{\circ} \mathrm{C}\right)$ for $48 \mathrm{~h}$. As additional food sources, we also included macroalgae, microphytobenthos and sediment data (along with the same sources mentioned before) for Potter Cove from Pasotti et al. (2015).

\subsection{Suspension/filter feeders}

The most representative suspension/filter feeders (Table 2) occurring in a randomly selected square meter patch were selected for stable isotope analysis. They were taken in the late summer of 2014 (beginning of March), by SCUBA diving between 10 and $15 \mathrm{~m}$ depth from three different stations with contrasting characteristics in terms of glacier-sedimentary regimes and distance from the glacier, following Jerosch et al. (2018) (Fig. 1). In the laboratory, animals were starved for one day in filtered seawater $(0.1 \mu \mathrm{m})$ to empty their gut. Shells of molluscs, carbonate skeleton of sea pens and tunics of ascidians were removed, and their muscle tissue dissected. Then, they were rapidly frozen in liquid nitrogen and stored at $-80{ }^{\circ} \mathrm{C}$ (Schaal et al., 2011). All samples were finally freeze dried $\left(\mathrm{P}=0.1 \mathrm{mbar}\right.$ and $\left.\mathrm{T}=-80{ }^{\circ} \mathrm{C}\right)$ for $48 \mathrm{~h}$.

\subsection{Sample preparation and stable isotope analysis}

Carbonates were removed from filter samples (food sources) and macroalgae detritus with $1 \mathrm{M} \mathrm{HCl}$ using the 'drop-by-drop' method recommended by Jacob et al. (2005), Kennedy et al. (2005) and Carabel et al. (2006).

Freeze-dried tissue samples were ground into a fine, homogeneous powder using an agate mortar and pestle, cleaning with methanol in between samples. Since they included no calcified tissues, no $\mathrm{HCl}$ treatment was needed to remove carbonates. Although lipids are depleted in ${ }^{13} \mathrm{C}$ and are thought to introduce bias into ${ }^{13} \mathrm{C}$ stable isotope analyses, lipid extraction was not applied before SI analysis, since the effect of it on the nitrogen signature is still under debate (Mintenbeck et al., 2008; Post et al., 2007). Thus, we used two mathematical normalizations, which use the carbon-to-nitrogen $(\mathrm{C}: \mathrm{N})$ ratio of a sample to normalize $\delta^{13} \mathrm{C}$ after analysis (Post et al., 2007; Logan et al., 2008). The first model (M1, Post et al., 2007) is a lipid-correction linear equation developed for aquatic animals: $\delta^{13} \mathrm{C}_{\text {lip-corr }}=\delta^{13} \mathrm{C}-3.32+0.99 \times \mathrm{C}: \mathrm{N}$. The second model (M2, Logan et al., 2008) is a lipid-correction equation for aquatic invertebrates: $\delta^{13} \mathrm{C}_{\text {lip-corr }}=\delta^{13} \mathrm{C}+3.3338-$ $((3.388 \times 3.314) / \mathrm{C}: \mathrm{N})$.

\subsection{Suspended particulate matter (SPM)}

Acidification of samples is a key step as it eliminates carbonates, which interfere with $\delta^{13} \mathrm{C}$ measurements. Its effect on $\delta^{15} \mathrm{~N}$ values is still unclear. Some authors reported that it significantly affects $\delta^{15} \mathrm{~N}$ values to a degree that may lead to confounding interpretations (Bunn et al., 1995; Pinnegar and Polunin, 1999), whereas others found only weak (Jacob et al., 2005) or even no significant effect (Bosley and Wainright, 1999). Overall, significant effects of acidification on $\delta^{15} \mathrm{~N}$ values appear to be caused by a prolonged (i.e., from 1 to $3 \mathrm{~h}$ ) incubation in acid (Carabel et al., 2006), which may induce a loss of dissolved organic matter during rinsing. Our own incubation times were much shorter (i.e., typically $<10 \mathrm{~min}$ ), and we are therefore confident in stating that our acidification procedure was appropriate for measuring $\delta^{15} \mathrm{~N}$. Powdered samples were weighed and put into clean tin cups before stable isotope analysis.

Carbon and nitrogen stable isotopes were analysed using an elemental analyser EA1108 (Carlo Erba Instruments) coupled to a massspectrometer MAT253 (ThermoFinnigan) at the Servizos de Apoio á Investigación de la Universidade de A Coruña (Spain). Isotopic ratios were expressed as parts per thousand (\%o) deviations from the conventional standards v-PDB (Pee-Dee Belemnite) for carbon and atmospheric $\mathrm{N}_{2}$ for nitrogen. Stable isotope concentrations were expressed in delta $(\delta)$ notation as parts per thousand according to the following equation:

$\delta(\%)=\left(R_{\text {sample }} / R_{\text {stan dard }}-1\right) \times 1000$

where $\delta(\%)$ is $\delta^{13} \mathrm{C}$ or $\delta^{15} \mathrm{~N}$; $\mathrm{R}_{\text {sample }}$ and $\mathrm{R}_{\text {standard }}$ are the proportion of ${ }^{13} \mathrm{C} /{ }^{12} \mathrm{C}$ or ${ }^{15} \mathrm{~N} /{ }^{14} \mathrm{~N}$ of the sample and the standard, respectively. Internal laboratory standards (acetanilide) with known isotopic composition were measured for instrument calibration after every 5th sample. The stability of the instrumentation, analytical precision, drift correction and linearity performance were calculated from the repetitive analysis of these standards and was $\pm 0.2 \%$.

The distances based permutational analysis PERMANOVA (Anderson, 2001) was used to evaluate the null hypothesis of no significant differences between raw $\delta^{13} \mathrm{C}$ values and those mathematically corrected for lipids (M1 and M2). The null hypothesis of no significant 
Table 2

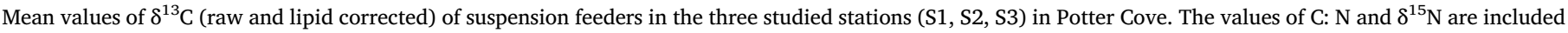
as reference.

\begin{tabular}{|c|c|c|c|c|c|c|c|c|}
\hline \multirow[t]{2}{*}{ Station } & \multirow[t]{2}{*}{ Species } & \multirow[t]{2}{*}{$\mathrm{n}$} & \multirow[t]{2}{*}{$\mathrm{C}: \mathrm{N}$} & \multirow[t]{2}{*}{$\delta^{13} \mathrm{C}(\%)$} & \multicolumn{2}{|c|}{ Lipids correction } & \multirow[t]{2}{*}{$\delta{ }^{15} \mathrm{~N}(\%$} & \multirow[t]{2}{*}{ Feeding mode } \\
\hline & & & & & $\mathrm{M}^{\mathrm{a}}$ & $\mathrm{M} 2^{\mathrm{b}}$ & & \\
\hline 1 & Molgula pedunculata & 2 & 3.46 & -25.89 & -25.78 & -25.80 & 3.21 & Filter feeder \\
\hline 1 & Molgula pedunculata & & 3.41 & -25.97 & -25.91 & -25.92 & 3.17 & Filter feeder \\
\hline 1 & Cnemidocarpa verrucosa & 2 & 3.75 & -25.41 & -25.02 & -25.07 & 3.64 & Filter feeder \\
\hline 1 & Cnemidocarpa verrucosa & & 3.95 & -25.44 & -24.85 & -24.95 & 3.77 & Filter feeder \\
\hline 1 & Ascidia challengeri & 2 & 3.67 & -24.75 & -24.43 & -24.47 & 4.16 & Filter feeder \\
\hline 1 & Ascidia challengeri & & 3.93 & -25.85 & -25.28 & -25.37 & 3.68 & Filter feeder \\
\hline 1 & Perkinsiana magalhaensis & 2 & 3.68 & -22.55 & -22.22 & -22.26 & 4.63 & Suspension/filter feeder \\
\hline 1 & Perkinsiana magalhaensis & & 3.66 & -22.95 & -22.65 & -22.69 & 4.71 & Suspension/filter feeder \\
\hline 2 & Malacobelemnon daytoni & 2 & 4.33 & -25.19 & -22.78 & -24.01 & 6.77 & Suspension feeder \\
\hline 2 & Malacobelemnon daytoni & & 4.35 & -24.83 & -23.84 & -24.08 & 7.05 & Suspension feeder \\
\hline 2 & Laternula elliptica & 2 & 4 & -23.06 & -22.42 & -22.53 & 3.09 & Filter feeder \\
\hline 2 & Laternula elliptica & & 4.14 & -22.87 & -22.09 & -22.25 & 3.67 & Filter feeder \\
\hline 3 & Ascidia challengeri & 1 & 3.99 & -26.43 & -25.80 & -25.91 & 4.73 & Filter feeder \\
\hline 3 & Corella antarctica & 3 & 4.55 & -28.50 & -27.31 & -27.63 & 3.12 & Filter feeder \\
\hline 3 & Corella antarctica & & 4.39 & -27.20 & -26.17 & -26.42 & 3.79 & Filter feeder \\
\hline 3 & Corella antarctica & & 4.53 & -28.41 & -27.25 & -27.56 & 3.71 & Filter feeder \\
\hline 3 & Molgula pedunculata & 3 & 3.83 & -27.34 & -26.87 & -26.94 & 1.84 & Filter feeder \\
\hline 3 & Molgula pedunculata & & 4.01 & -27.56 & -26.91 & -27.03 & 2.15 & Filter feeder \\
\hline 3 & Molgula pedunculata & & 3.85 & -27.36 & -26.87 & -26.94 & 1.69 & Filter feeder \\
\hline 3 & Pyura bouvetensis & 3 & 4.21 & -28.21 & -27.36 & -27.54 & 4.57 & Filter feeder \\
\hline 3 & Pyura bouvetensis & & 4.37 & -27.96 & -26.96 & -27.20 & 4.50 & Filter feeder \\
\hline 3 & Pyura bouvetensis & & 4.59 & -27.80 & -26.58 & -26.92 & 4.23 & Filter feeder \\
\hline 3 & Pyura setosa & 1 & 4.14 & -27.80 & -27.02 & -27.18 & 4.46 & Filter feeder \\
\hline 3 & Synoicum adareanum & 1 & 4.97 & -28.28 & -26.68 & -27.20 & 4.04 & Filter feeder \\
\hline 3 & Perkinsiana magalhaensis & 1 & 4.2 & -23.21 & -22.37 & -22.55 & 6.91 & Suspension/filter feeder \\
\hline
\end{tabular}

${ }^{\text {a }}$ Model 1 (Post et al., 2007): $\delta^{13} C_{\text {lip-corr }}=\delta^{13} C-3.32+0.99 \times C: N$.

b Model 2 (Logan et al., 2008): $\delta^{13} C_{\text {lip-corr }}=\delta^{13} C+3.3338-((3.388 \times 3.314) / C: N)$.

differences of $\delta^{13} \mathrm{C}$ and $\delta^{15} \mathrm{~N}$ isotopic signatures between the three stations (S1, S2, S3) was also tested by means of PERMANOVA. The analyses (with 10,000 permutations) were executed with the PAST software (Hammer et al., 2001), using the Euclidean distance, so the the pseudo-F statistic values are equivalent to the ANOVA F (Anderson, 2001).

Bayesian mixing model approach allows incorporating variable sources in organisms and food source signatures, as well as in trophic fractionation. The upgrade function simmr (Parnell, 2016) from the package SIAR (Stable Isotope Analysis within R) (Parnell et al., 2010) was used to estimate the relative contribution of each food source at the study sites and to the consumers' diet. Models were built over four Markov chains with 10,000 steps per chain and a burn-in of 500,000 iterations whereas 50,000 initial iterations were discarded. The information supplied to the model included the isotopic data of consumers (suspension or filter feeders), the potential food sources and the trophic enrichment factors. For consumers (suspension and filter feeders) were used the $\delta^{13} \mathrm{C}$ values corrected according to the M1 model (Post et al., 2007). Trophic enrichment factors in the Southern Ocean are still not well understood (Post, 2002; McCutchan et al., 2003; Jia et al., 2016). For the sake of comparison with other studies (Pasotti et al., 2015; Jia et al., 2016; Servetto et al., 2017), we used the trophic enrichment factors proposed by McCutchan et al. (2003) of $2.2 \pm 0.3 \%$ and $0.5 \pm 0.13 \%$, for $\delta^{15} \mathrm{~N}$ and $\delta^{13} \mathrm{C}$ respectively.

\section{Results}

Considering all consumers together without taking into account the feeding mode (suspension vs filter feeder) nor the identity of the species, the $\delta^{13} \mathrm{C}$ composition (Fig. 2) differed significantly between the three sampling stations from Potter Cove (pseudo-F $=5.77$, $\mathrm{p}<0.001$, Table 2). Suspension feeders from S2 (halfway to the front of the glacier) exhibited most enriched values of $\delta^{13} \mathrm{C}(-22.78 \%)$ than in the other two stations. The most depleted $\delta^{13} \mathrm{C}$ values $(-26.81 \%$ ) were observed in S3 (far from the front of the glacier), followed by the station closest to the glacier (S1, $-25.2 \%$ ). The $\delta^{15} \mathrm{~N}$ values (Fig. 2) for S2 (4.51\%o) was significantly different from S3 (3.46\%) and marginally different from $S 1(3.6 \%)$ ) (pseudo-F $=5.02, p=0.02$, Table 3 ). When considering only the filtering species (ascidians and the clam Laternula elliptica) significant differences in $\delta^{13} \mathrm{C}$ were observed (Fig. 3) between the three stations (pseudo-F $=84.54, \mathrm{p}=0.0001$ ) but not for the $\delta^{15} \mathrm{~N}$ values (pseudo-F $=0.047, \mathrm{p}=0.96$ ) (Fig. 3). Within each station (S1, $\mathrm{S} 2$ or S3), no differences in $\delta^{13} \mathrm{C}$ were observed $(\mathrm{p}>0.05)$ between suspension and filter feeders, nor between the different species. However, the sea pen Malacobelemnon daytoni and the polychaete Perkinsiana magalhaensis showed the most enriched values of $\delta^{15} \mathrm{~N}$ (6.98 $\pm 0.2 \%$ and $6.62 \pm 0.3 \%$, respectively) (Fig. 3).

The distribution of isotopic signatures of consumers falls within the polygon defined by the considered food sources (Fig. 4), thus, the mixing model was consistent and no important food sources were missed in the present study. The assimilation of $\delta^{13} \mathrm{C}$ and $\delta^{15} \mathrm{~N}$ derived from the considered food sources differed among stations in Potter Cove (Fig. 5). Overall, the SIAR output indicated that, for most of the consumers analysed, contributions of SPM and macroalgae detritus tended to prevail over the rest of the potential food sources (Fig. 5). Food sources contribution was similar in S1 and S2. However, values in S3 differed as macroalgae detritus was found to be the main source of organic carbon (Fig. 5). Krill faeces came up thirdly as food source (Fig. 5) in S3 although their contribution was similar in all three stations, with an average mode of $16.69 \%$ ( \pm 0.68 ). Although macroalgae detritus contribution in the diet was higher in S3 than in the other stations, its contribution to the S3 consumers diet represented a smaller proportion (mode: 10.68\%) in relation to the inner stations S1 (mode: 14.77\%) and S2 (mode: 13.05\%) (Fig. 5). The contribution of microphytobenthos and superficial bottom sediments was low or absent in S3, but had greater contribution in the inner stations (S1 and S2) 


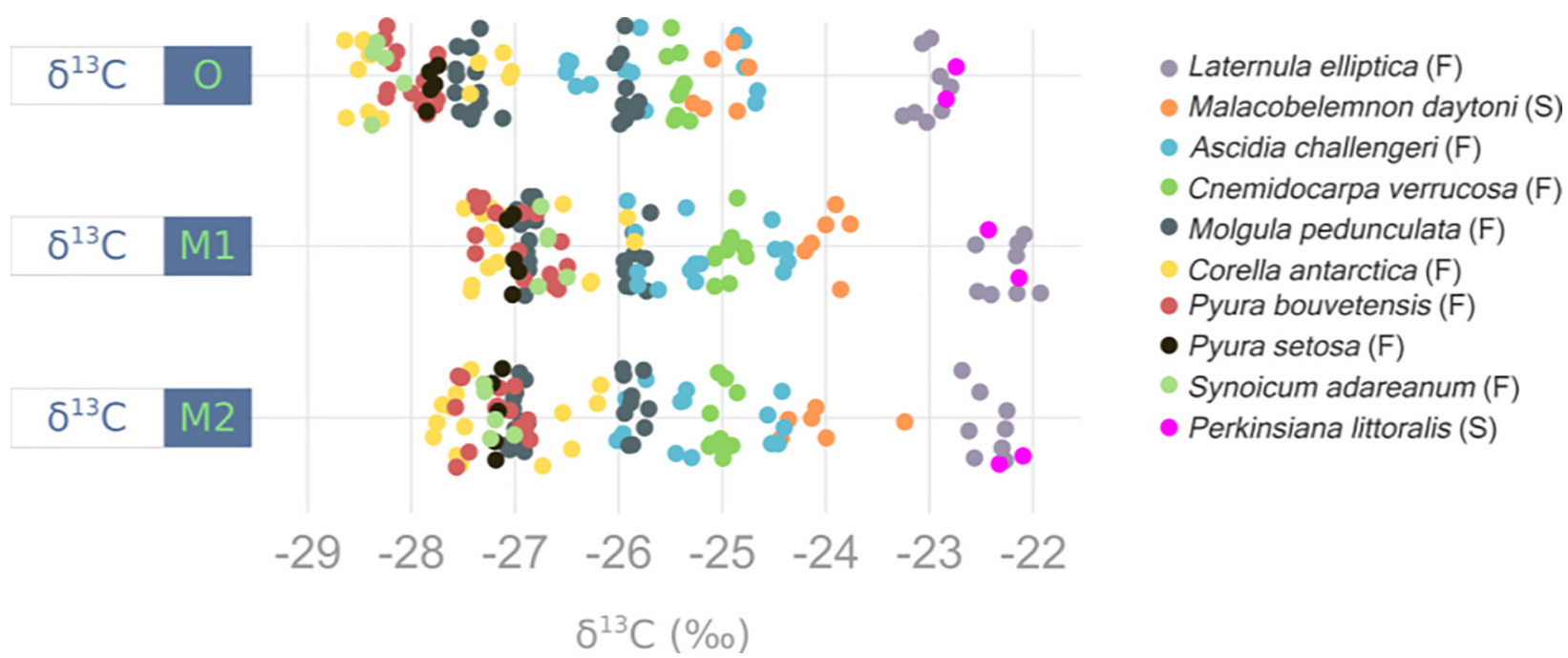

Fig. 2. Comparison of the measured (raw) and $\delta^{13} \mathrm{C}$ lipid corrected values of macrobenthic consumers in Potter Cove. $\delta^{13} \mathrm{C} O$ represent the measured values for the carbon isotope (uncorrected); $\delta^{13} \mathrm{C} \mathrm{M} 1$, the corrected values according to the model of Post et al. (2007); $\delta^{13} \mathrm{C} \mathrm{M} 2$, the corrected values, according to the model of Logan et al. (2008). Different colors indicate different species. Species present in more than one station, show a wide dispersion on the $\mathrm{x}$-axis, while the closest points come from the same station (note for example Molgula pedunculata (gray points), grouping close to $-27 \%$ (S3) and $-26 \%$ (S1)). (S): suspension feeder; (F): filter feeder.

Table 3

PERMANOVA pairs comparisons (over 10,000 permutations) for the variation of $\delta^{13} \mathrm{C}$ and $\delta^{15} \mathrm{~N}$ between the three sampling stations (S1, S2, S3) in Potter Cove. Values above the main diagonal indicate the significance level $(p)$; bold values indicate significant values $(p<0.05)$. Values below the main diagonal indicate pseudo-F values for each comparison.

\begin{tabular}{llllllll}
\hline$\delta^{13} \mathrm{C}$ & $\mathrm{S} 1$ & $\mathrm{~S} 2$ & $\mathrm{~S} 3$ & $\delta^{15} \mathrm{~N}$ & $\mathrm{~S} 1$ & $\mathrm{~S} 2$ & $\mathrm{~S} 3$ \\
\hline $\mathrm{S} 1$ & - & $\mathbf{0 . 0 4}$ & $\mathbf{0 . 0 0 0 5}$ & $\mathrm{S} 1$ & - & 0.06 & 0.94 \\
$\mathrm{~S} 2$ & 3.09 & - & $\mathbf{0 . 0 0 8}$ & $\mathrm{S} 2$ & 5.58 & - & $\mathbf{0 . 0 2}$ \\
$\mathrm{S} 3$ & 11.75 & 7.98 & - & $\mathrm{S} 3$ & 0.006 & 7.03 & - \\
\hline
\end{tabular}

\section{SUSPENSION FEEDERS}
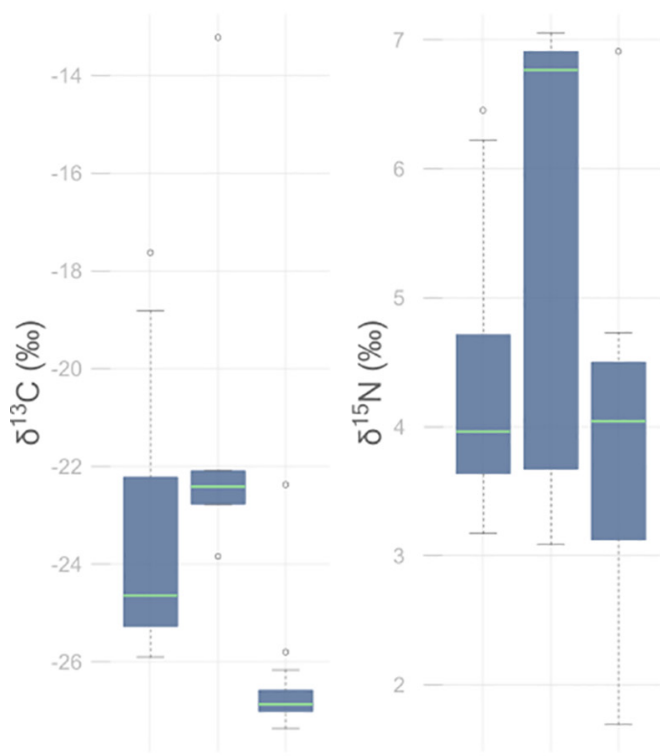
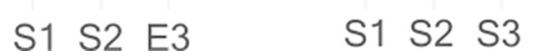

although not in the same way. Only a significant contribution of microphytobenthos was found in S2 (mode: 16.07\%). Likewise, the contribution of superficial bottom sediments was between two and three times higher in the diet of consumers in S2 (Sed-S1 mode: 15\%, Sed-S2 mode: $11.71 \%$ ) than in S1 (Sed-S1 mode: 3\%; Sed-S2 mode: $6.4 \%$ ) although the $\mathrm{IC}_{95}$ values were similar in all cases. Phytoplankton contribution was notably higher (up to five times) in the internal stations (S1 mode: $15.53 \%$, S2 mode: $14.26 \%$ ) than in S3, where the proportional contribution was almost negligible (mode: $3 \%$ ).

Although the $\delta^{13} \mathrm{C}$ values of consumers presented a wide range of variation $(-27.36$ to $-13.22 \%$ ), the overall pattern observed for the

Fig. 3. Spatial isotopic characterisation of Potter Cove. Comparison of the stable isotopes $\delta^{13} \mathrm{C}(\%)$ corrected (M1) and $\delta^{15} \mathrm{~N}(\%)$ measured for: a) all suspension (M. daytoni and $P$. littoralis) and b) filter feeders (A. challengeri, C. verrucosa, C. antarctica, M. pedunculata, P. bouvetensis, P. setosa, S. adareanum and L. elliptica) present in each season. The box-plot represents the median (in green), the second and third quartiles (upper and lower limit, respectively). The whiskers express the maximum value defined as the interquartile range multiplied by the factor 1.5 . 


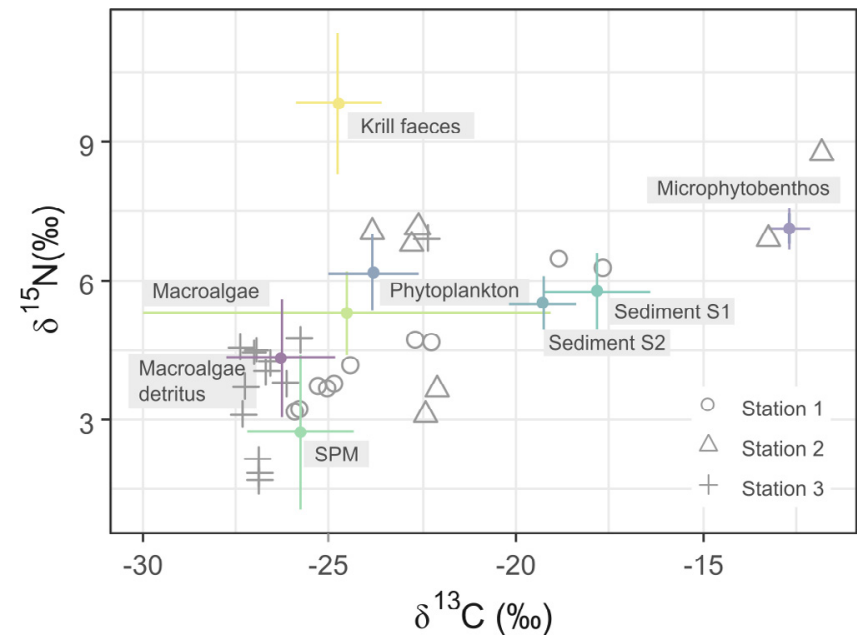

Fig. 4. $\delta^{13} \mathrm{C}(\%)$ and $\delta^{15} \mathrm{~N}(\%)$ ratios for suspension-feeders and their potential food sources from Potter Cove, . Bivariate graph constructed using the Bayesian SIAR mixing model (Parnell et al., 2010). The error bars represent the $95 \%$ confidence intervals and incorporate the standard deviation in the sources isotopic signatures and the fractionation factors $\left(2.2 \% \pm \pm 0.3\right.$ for $\delta^{15} \mathrm{~N}$ and $0.5 \%$ o \pm 0.13 for $\delta^{13} \mathrm{C}$ ). SPM: suspended particulate matter, S1: station 1 (close to the glacier, high sedimentation), S2: station 2 (intermediate distance and sedimentation), S3: station 3 (away from the glacier, low or no sedimentation).

analysis of food sources per station was mirrored by the consumers in each station, showing about the same food sources contribution (Fig. 6), independent of the species identity. However, the sea pen Malacobelemnon daytoni and the polychaete Perkinsiana magalhaensis, showed some differences in the food contribution estimation for S2 (Fig. 6). Krill faeces and microphytobenthos resulted to contribute more to the diet of those species, respectively (Fig. 6).

\section{Discussion}

\subsection{Food sources}

While $\delta^{15} \mathrm{~N}$ values have a wide range of variation among food sources (i.e. SPM $<$ detritus $<$ phytoplankton $<$ krill faeces), the overlapping of depleted $\delta^{13} \mathrm{C}$ signatures of SPM, phytoplankton, detritus and krill faeces indicates that the benthic suspension feeders of
Potter Cove are sustained by a mixing of fresh and detrital food sources. Isotopic signatures of SPM and phytoplankton, coincides with those previously reported for Potter Cove (Pasotti et al., 2015) and Martel Inlet (Corbisier et al., 2004), but they are higher than those recently reported for Fildes Bay (Zenteno et al., 2019). The $\delta^{13} \mathrm{C}$ values of phytoplankton, although impoverished compared to those reported for oceanic waters (Wada et al., 1987), are coincident with the signatures observed in the Bransfield Strait area (Khim et al., 2005). Carbon impoverishment in coastal Antarctic phytoplankton might be a consequence of the fractionation process during carbon fixation, as high levels of $\mathrm{pCO}_{2}$ on the sea surface along with a low growth rate in low light intensity conditions are linked to more negative values of $\delta^{13} \mathrm{C}$ (Wada et al., 1987). This could explain the values obtained for Potter Cove, considering that the development of phytoplankton during the summer (Schloss et al., 2014) occurs in reduced light conditions, due to the turbidity generated by sediment washed by meltwater runoff (Schloss et al., 2012; Deregibus et al., 2016). In addition, $\mathrm{pCO}_{2}$ in Antarctic coastal areas tends to be elevated during the summer (Tortell et al., 2014; Kapsenberg et al., 2015).

Macroalgae detritus and krill faeces are carbon depleted in comparison to fresh macroalgae and phytoplankton in Potter Cove. Fisher and Wiencke (1992) noticed an impoverishment in decaying macroalgae fragments, which is coincident with the detritus' $\delta^{13} \mathrm{C}$ in Potter Cove. In addition, the low values of $\delta^{13} \mathrm{C}$ are attributable to Desmarestiales (Fisher and Wiencke, 1992). The latter is among the most conspicuous macroalgae group reaching high abundances (up to $80 \%$ of the biomass) in the study area (Quartino and Boraso de Zaixso, 2008; Quartino et al., 2013). On the other hand, krill faeces usually shows more enriched $\delta^{13} \mathrm{C}$ values ( $\sim 2 \%$ ) than phytoplankton, although it may not occur when derived from specific diets (Fisher, 1991) as was done in the present study. Indeed, krill faeces were carbon depleted in relation to phytoplankton, but a bit more enriched $(\sim 1 \%)$ than SPM. This carbon enrichment seems to be a consequence of the selectivity for the light isotope $\delta^{12} \mathrm{C}$ during faeces production throughout the krill's digestion process (Rau et al., 1983). Given that the faeces used in the present study were obtained from krill incubations under natural seston conditions (Alurralde et al., 2019) and considering the enrichment ratio regarding to SPM, it is probable that the provided food in the krill incubation had a higher proportion of macroalgae detritus than phytoplankton.

Superficial bottom sediments were $\delta^{13} \mathrm{C}$ enriched (7\%) in relation to pelagic SPM, even when the shallow depth in Potter Cove would

\section{$\begin{array}{lll}\text { STATION } 1 & \text { STATION } 2 & \text { STATION } 3\end{array}$}

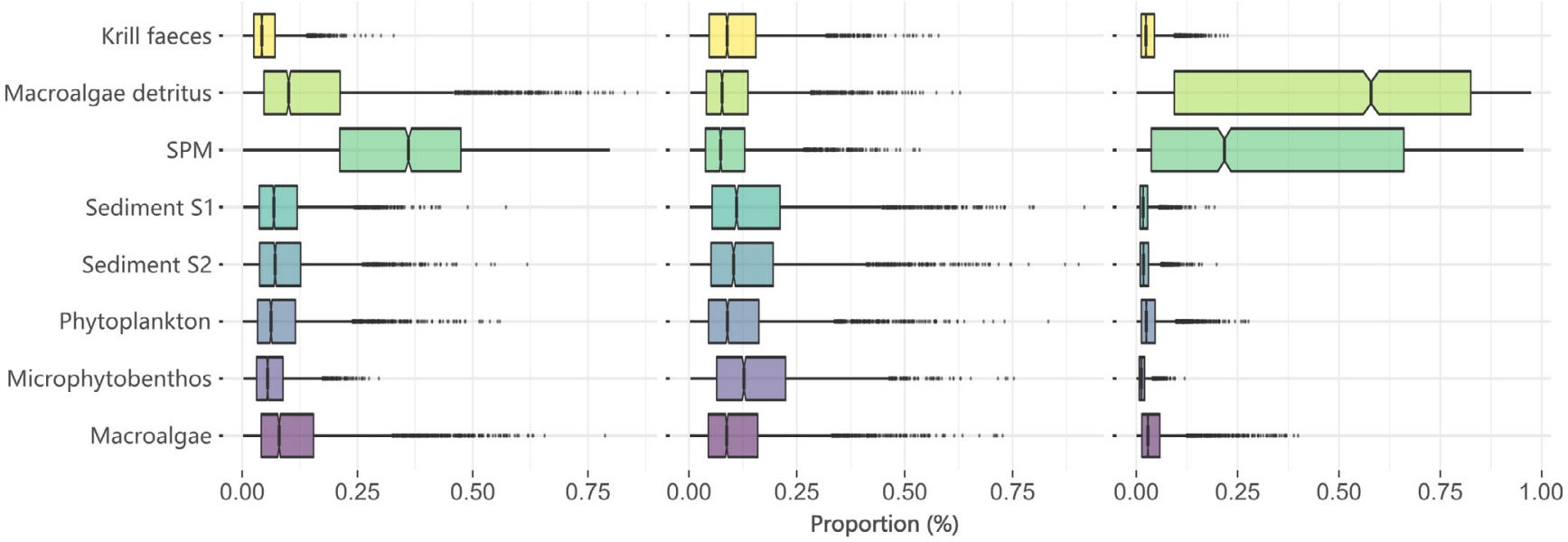

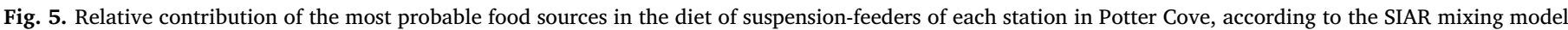

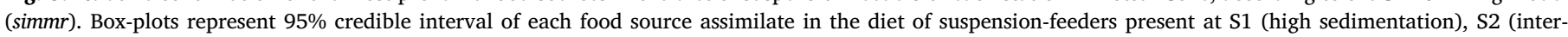

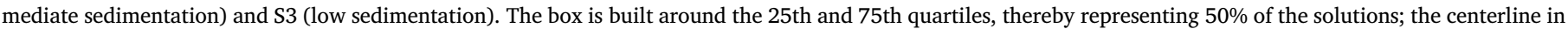
the box indicate the median of all solutions. 


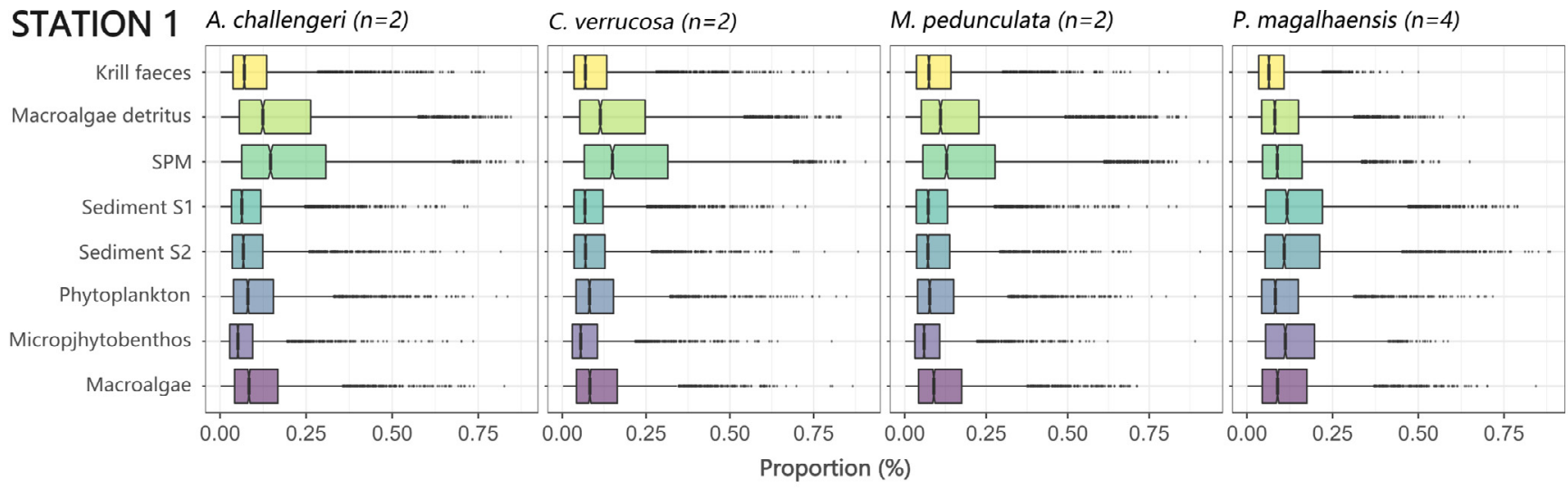

STATION 2 L. elliptica $(n=2)$

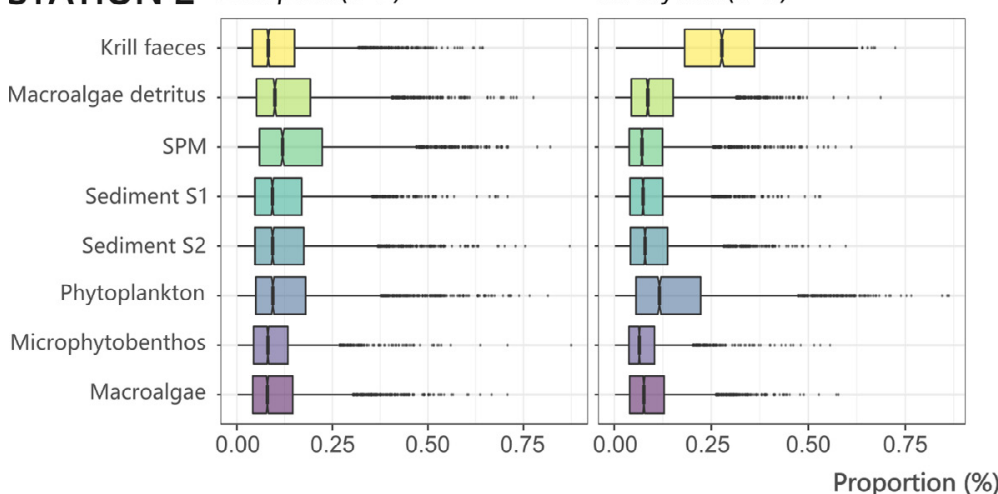

P. magalhaensis $(n=2)$

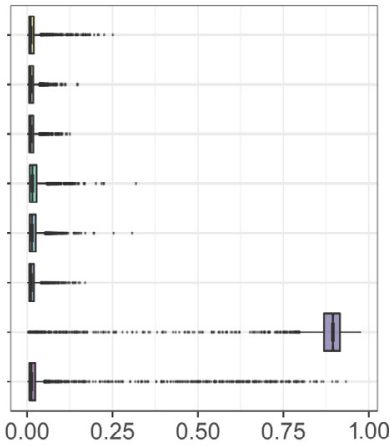

STATION 3 A. challengeri $(n=1)$

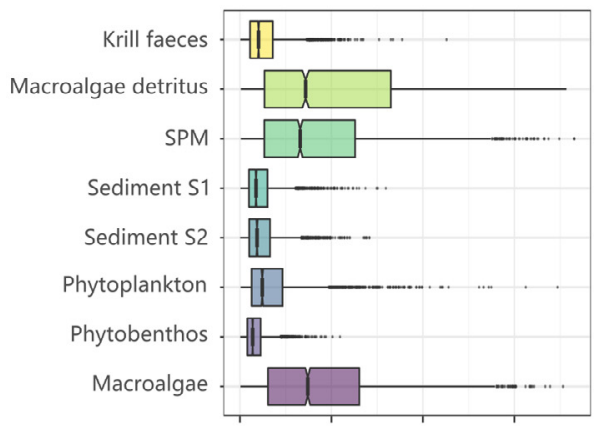

$P$. bouvetensis $(n=2)$

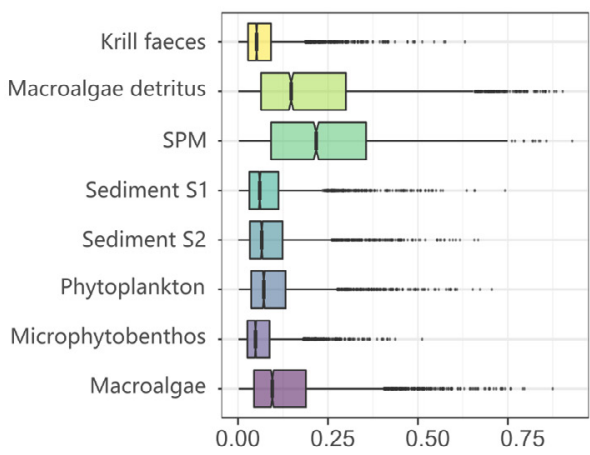

C. antarctica $(n=3)$

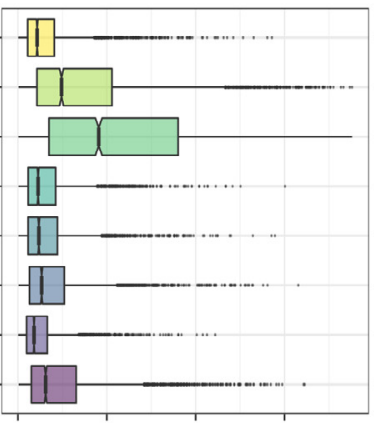

P. setosa $(n=1)$

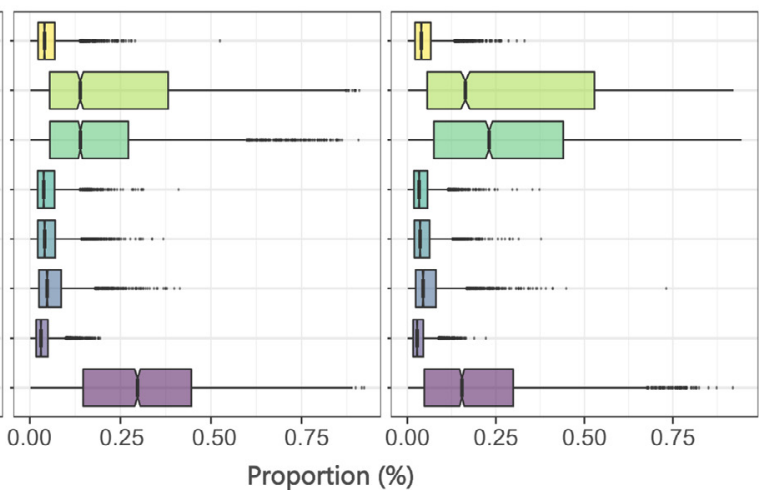

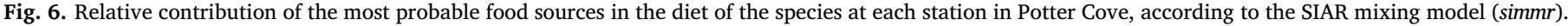

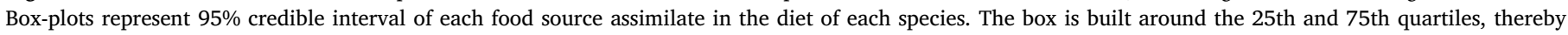
representing $50 \%$ of the solutions; the centerline in the box indicate the median of all solutions. 
favor a faster particulate matter sinking and therefore, similar isotopic signatures between pelagic and seabed particles were found. In Fildes Bay, the same pattern was recently reported (Zenteno et al., 2019). It is probable that this signature has resulted from the presence of microphytobenthos, once it has more enriched values $(\sim 5 \%)$ than superficial bottom sediments and SPM (> 10\%) (Pasotti et al., 2015; Ha et al., 2019). Microphytobenthos with colonial formation over soft sediments was observed in experimental conditions (Alurralde and Campana, 2017) and in recent colonisation experiments in the upper subtidal of Potter Cove (Campana et al., 2018), indicating that its development is especially relevant in the inner cove (in our study S1 and S2). In addition, there are reports of large mats development in the inner part of Potter Cove (Hoffmann et al., 2018, 2019) and in the adjacent fjord Marian Cove (Ahn et al., 2016) where it seems to be an important food source for benthic suspension feeders (Ha et al., 2019). Since superficial bottom sediments integrate several sources and its value would reflect (like the pelagic SPM) an average of the whole set of sources, it is not surprising that the $\delta^{13} \mathrm{C}$ values of the sediment are intermediate between the microphytobenthos and pelagic SPM. Furthermore, these values are similar to those reported by Corbisier et al. (2004) and Zenteno et al. (2019) for other coastal areas of King George Island and for other sub-Antarctic coastal areas in the Strait of Magellan (Aracena et al., 2011; Andrade et al., 2016).

The considered food sources varied $\sim 2 \%$ in their $\delta^{15} \mathrm{~N}$ composition. This isotope composition depends mainly on the dynamics of the different sources of inorganic nitrogen (nitrates, ammonium and $\mathrm{N}_{2}$ ) in the water column (Altabet, 1988) and the fractionation during assimilation processes (Montoya and McCarthy, 1995). Low values of $\delta^{15} \mathrm{~N}$ in SPM are common in polar environments and have been attributed to the incorporation of recycled ammonium (Probyn and Painting, 1985; Smith and Nelson, 1990; Trull et al., 2014) during the development of phytoplankton in low light conditions when nitrate is not a limiting substrate (Koike et al., 1986; Morales et al., 2014). The SPM used in this study was collected in the inner part of Potter Cove, where despite the absence of nitrate limitations, photosynthesis is limited by high levels of turbidity (Schloss et al., 2002; Deregibus et al., 2016; Campana et al., 2018; Hoffmann et al., 2019). This SPM presented the most impoverished value of all sources and was within the ranges normally reported for Antarctic waters (Mincks et al., 2008; Choy et al., 2011; Jia et al., 2016). Phytoplankton, on the other hand, was collected in the outer part of Potter Cove, under more oceanic conditions to avoid contamination with detrital material and to obtain a 'pure' phytoplankton signal (Schaal et al., 2008). This is perhaps the reason for the enriched $\delta^{15} \mathrm{~N}$ value in phytoplankton relative to SPM (Gillies et al., 2012; Jia et al., 2016). On the other hand, microphytobenthos had even more enriched values than phytoplankton, possibly linked to the use of nitrates as substrate (Nedwell and Walker, 1995), especially coming from the high amount of decaying macroalgae detritus in the sediments of Potter Cove (Braeckman et al., 2019). Antarctic macroalgae species are known to show great variability in $\delta^{15} \mathrm{~N}$ (Dunton, 2001). The value presented in the present study comes from Pasotti et al. (2015) based on a mixture of seven representative species from Potter Cove that were not further detailed in that study. However, both isotope compositions $\left(\delta^{15} \mathrm{~N}\right.$ and $\left.\delta^{13} \mathrm{C}\right)$ coincided with species such as Desmarestia anceps, $D$. menziesii, Himantothallus grandifolius and Palmaria decipiens from other Antarctic regions (Dunton, 2001), that are the most abundant species in Potter Cove (Quartino and Boraso de Zaixso, 2008; Quartino et al., 2013). A possible bacterial activity could explain the great enrichment observed in the faeces (Arístegui et al., 2014; Morata and Seuthe, 2014).

\subsection{Spatial variation along a sedimentation gradient}

A single set of food sources was considered for Potter Cove, but differences were observed along the fjord in the $\delta^{13} \mathrm{C}$ and the $\delta^{15} \mathrm{~N}$ ratios of suspension feeders subjected to different sedimentation regimes related to the influence of glacier discharge. The mixing models corroborate that resources are spatially segregated, once their contribution to suspension feeders diet was different between the internal stations (S1 and S2) and the external one (S3), estimating a more heterogeneous availability in the first two. The discharge of meltwater with sediment has been also associated as a controlling factor of food variability in Arctic fjords (Zajączkowski et al., 2010). This adds to a recently discussion introduced by Zenteno et al. (2019) who argued that spatial variability in food source in hydrographically complex areas (Barnes and Clarke, 1995; Tu et al., 2015), as nearshore Antarctic systems, constitute a relevant confounding factor to be considered in the study of trophic pathways.

Our study indicates that the benthos in Potter Cove has access to a heterogeneous pool of food sources, whose contribution varies spatially related to the distance from the front of the Fourcade Glacier. The consumers showed different $\delta^{13} \mathrm{C}$ and $\delta^{15} \mathrm{~N}$ signatures in the three stations (S1, S2 and S3), although the greatest differences were given by $\delta^{13} \mathrm{C}$ composition. The low variation in $\delta^{15} \mathrm{~N}$ is not unexpected since the studied organisms occupy the same trophic level (Pasotti et al., 2015). The $\delta^{13} \mathrm{C}$ followed the same variation among stations, in spite of the differences observed when considering all suspension feeders as a whole or only the filter feeders. However, species composition at each station may have exerted some bias on the signature of both stable isotopes. Suspension feeders constitute a functional unit (Dame et al., 2001) exhibiting several feeding modes with different capacities and selective efficiencies (Riisgård and Larsen, 2010). Some species are even able to change their feeding strategies depending on the availability of food, such as Perkinsiana littoralis, which can alternate between detritivore or filter feeder (Gambi et al., 1997, Kröger and Rowden, 2008), or Malacobelemnon daytoni, which can incorporate sources of animal origin (Servetto et al., 2017). This was evident in the mixing models output and explain the amplitude of the $\delta^{15} \mathrm{~N}$ signals, since considering a trophic enrichment factor of $2.2 \%$ o (McCutchan et al., 2003), the sea pen should occupy a different trophic level (Fry 2006). While ascidians do not exert any sort of selection on the material they filter (Petersen, 2007), Laternula elliptica might selectively filter phytoplankton and reject inorganic material (Ahn, 1993). However, the $\delta^{13} \mathrm{C}$ values do not support any food selection, but an opportunistic assimilation of the available food sources at each station (Coma et al., 2001). The constrained number of organisms in our analysis would be arguable of leading to biased conclusions. However, the consistency between the isotopic signatures of suspension and filter feeders within each station allows to support the idea of spatial segregation of food sources in Potter Cove.

Macroalgae detritus and SPM were the dominant food sources in the inner part of Potter Cove, confirming previous experimental findings (Alurralde et al., 2019; Braeckman et al., 2019). The same is reported for benthic suspension feeders of Fildes Bay (Zenteno et al., 2019), although the analysis in that study was done on the filter feeders $L$. elliptica and Kidderia bicolor. Macroalgae in Potter Cove are represented by a very abundant, complex and diverse community that represent $97.8 \%$ of the fjord summer production (Quartino and Boraso de Zaixso, 2008). Although the highest biomass of macroalgae occurs in the external zone (Klöser et al., 1996; Quartino et al., 2005), they have been able to colonise newly free-ice areas in the inner part of Potter Cove (Quartino et al., 2013; Lagger et al., 2017; Campana et al., 2018). Fresh material of Desmarestiales is apparently unpalatable for some species (Amsler et al., 2005), so its contribution to suspension feeders' diet would be restricted. Nevertheless, macroalgal carbon can enters the coastal food web after algal tissues die and begin to decompose (Amsler et al., 2012; Braeckman et al., 2019). Thus probably Desmarestia carbon is indirectly available for suspension feeders after bacteria and microphytobenthos recycling (Braeckman et al., 2019). Indeed, two of the most abundant suspension feeders in Potter Cove, the ascidian C. verrucosa and the sea pen $M$. daytoni, are known to feed on and assimilate macroalgae detritus (Tatián et al., 2008; Servetto et al., 2017; Alurralde 
et al., 2019).

On the other hand, krill faeces is a frequently occurring and highly abundant component of the summer downward particle flux (Alurralde, 2018). By incorporating this item as a potential food source in the trophic analysis, our study also indicates that krill faeces is part of the carbon assimilated during the summer in Potter Cove. Even though krill is not a permanent resident in Potter Cove (Fuentes, 2006; Garcia et al., 2016), krill schools frequently enter the fjord driven by currents and find high levels of suspended sediment in the inner part. Once krill starts to feed in this turbid water, the ingestion of inorganic particles triggers a higher faeces production rate (Fuentes et al., 2016; Alurralde et al., 2019), which favors a high provision of this food source (Alurralde et al., 2019). This particular finding, highlights that would be worthy to widening the assessment of carbon assimilation including further potential primary food sources (e.g. allochthonous material, filamentous algae, bacterio and microplankton), as we did here with krill faeces. This would allow to build more robust generalisations of trophic pathways within coastal Antarctic ecosystems. It further underlines the importance of a tight bentho-pelagic coupling as the benthic feeders largely depend on the input from the water column.

\subsection{Environmental drivers of food sources in Potter Cove}

In Arctic fjords the quality and quantity of food sources for the benthos are controlled by a complex interaction between environmental factors (e.g. hydrography, ice cover, bathymetry, bottom morphology, sedimentology) and biological factors (e.g. primary producers, productivity, grazing efficiency, bacterial activity) acting at different scales (Wassmann et al., 2006; Zajączkowski et al., 2010; Anderson and Macdonald, 2015; Zaborska et al., 2016). Similarly, in our study system some of them can be involved as drivers of the observed spatial distribution of food sources. In Potter Cove, circulation is caused by a cyclonic gyre that enters through the north coast (Roese and Drabble, 1998), where it develops one of the most important macroalgae communities (Quartino et al., 2005) and where sampling station S3 is located. In addition to this circulation, a strong erosive energy (produced by the variation of the tidal height) impacts mainly the bedrock that characterizes the north coast of Potter Cove (Wölfl et al., 2014). This erosive force would be greater in shallow areas (Wölfl et al., 2014) and could favour the abrasion of macroalgae thallus, generating fragments susceptible of being colonized by bacteria (Quartino et al., 2015) and later enter the detritus pool. Once they became free-driving, water circulation driven by westerly winds can transport this debris to the inner part of Potter Cove (Schloss et al., 1997). The mixing model outcome indicated that macroalgae have a lower contribution as food source in S2, although this station should receive material from S3 considering the circulation system in Potter Cove. Once easterly winds drive changes in the upper circulation, pushing surface water out of Potter Cove, it will prevent the displacement of macroalgae towards the interior of the fjord (Schloss et al., 1997, 2012, Wölfl et al., 2014). On the other hand, the slightly higher contribution in S1 could be due to the seasonal input of perennial algae (Desmarestiales), which colonize the newly ice-free inner areas (Quartino et al., 2013). Despite the mixing models suggesting a potential contribution of macroalgae to the diet of benthic suspension feeders in Potter Cove, it is not conclusive due to the limited confidence intervals estimated by the models.

The complex hydrographical settings in Potter Cove might lead to spatial variability in advection processes, or increased deposition affecting also the assimilation of food sources by consumers ( $\mathrm{Tu}$ et al., 2015). The bottom topography of Potter Cove and the loss of erosive energy towards the inner fjord, determine two depocenters of particulate matter and sediments (Wölfl et al., 2014). One is allocated in the inner cove, where there is also an internal gyre that increases the water residence time and therefore, of the particles that accumulate there. The second depocenter develops on the central axis of the fjord and extends towards the south coast of Potter Cove (Wölfl et al., 2014).
These elements allow us to suppose that the hydrographic conditions that generate the first depocenter would be involved in the provision of almost all food sources estimated for S1. Meanwhile, the provision of macroalgae detritus to S3 could be explained by the partial exchange at the fjord mouth, where incoming and outgoing water masses are found (Roese and Drabble, 1998). In the same way, the contribution of sediments and microphytobenthos was circumscribed to the internal stations (S1 and S2), which is not surprising (Campana et al., 2018; Hoffmann et al., 2018, 2019). Although resuspension events are frequent in the inner cove (Schloss et al., 2012), hydrological conditions favor a sedimentation gradient of finer particles towards the glacier front (Wölfl et al,. 2014; Monien et al., 2017). There, the erosive energy, the low wave action and tidal height restrict the movement of sedimentary material confined to the inner area of Potter Cove (Wölfl et al., 2014). It would be through such resuspension events that microphytobenthos and sediments become available to the suspension feeders (Ha et al., 2019).

\subsection{Methodological remarks}

Lipids have impoverished values of $\delta^{13} \mathrm{C}$ (more negative) than any other biochemical component (Post et al., 2007; Logan et al., 2008), so they are usually removed prior to analysis. However, up to now, a standardised and reliable method based on a clear consensus has not been developed yet as it is known to have consequences on the $\delta^{15} \mathrm{~N}$ composition (Jacob et al., 2005; Post et al., 2007; Logan et al., 2008; Mintenbeck et al., 2008). Chloroform-methanol extraction is often used for lipids remotion, requiring duplicate samples and being highly time and effort consuming. Alternatively, the use of mathematical corrections after isotopes measurements seems more convenient and costbenefit and yielding reliable results (Logan et al., 2008).

Although both models for lipids correction (M1 and M2), had a similar performance (increase of of $\delta^{13} \mathrm{C}$ values), M1 was adopted (Post et al., 2007) because M2 (Logan et al., 2008) showed more conservative values for species with C:N ratio, close to 5 . The same was observed for zooplankton species from East Antarctica (Jia et al., 2016) and for $M$. daytoni in Potter Cove (Servetto et al., 2017). According to Logan et al. (2008) specific models should be selected for each species; however there are only few available, such as for krill (Logan et al., 2008). It should be noted that the application of different correction models could lead to different ecological interpretations if they are not properly evaluated before their election (Jia et al., 2016). As long as there is no general consensus model, it is important to report the raw $\delta^{13} \mathrm{C}$ values in order to be able to compare results with other studies (Jia et al., 2016).

\subsection{Future perspectives}

Several species-specific biological processes shape ecosystem functioning (Barnes and Sands, 2017), like $M$. daytoni or P. littoralis that alternate between trophic levels, increasing the trophic complexity of the system; or ascidians that are able to feed on detritus promoting the incorporation and mobilization throughout the food web of macroalgae's carbon and nitrogen. Nevertheless, in Potter Cove, the determined spatial patterns in the isotopic composition of suspension feeders suggest that regional warming (Vaughan et al., 2003; Cook et al., 2016; Spence et al., 2017), is capable of altering the quantity and possibly, the quality of the food sources that nourish the benthos. After fifteen years of monitoring of the macrobenthos in Potter Cove (Sahade et al., 2015), the increase in density/percentage cover relationship in the inner fjord (coincident with our S1) corroborated a decrease in the size of suspension feeders. More recently, it was estimated a highly negative energy balance in suspension feeders promoted by the low quality food available at S1 (especially due to the presence of suspended sediments), that would eventually compromise the last benthic secondary production (somatic growth) (Alurralde et al., 2019). Thus, 
as the abundance and distribution of benthic suspension feeders rely on the characteristics of food supply (Gardner, 2000; Rossi et al., 2015; Jansen et al., 2018a,b), the injection of sediment from the runoff of land-terminating glaciers might reshape the carbon dynamics with drastic repercussions on the trophic web and hence in the whole ecosystem. As a result of local variations in biological and environmental conditions, climate change effects on the marine ecosystem can vary between different fjord systems (Wassmann et al., 2006; Anderson and Macdonald, 2015; Zaborska et al., 2016). However, glacial fjords have a paramount role in the global carbon cycle (Smith et al., 2015). Potter Cove is a representative fjord on King George Island and this study give insights into the consequences of glacial melting over food supply. Furthermore, extensive fjordic areas are following the same landward deglaciating trend, so it is likely that such systems will face similar conditions to those reported here.

\section{Conclusions}

To sum up, our study confirms the hypothesis that multiple primary food sources are assimilated by lower trophic levels and that they are spatially segregated mainly due to glacial melt-related retreat environmental conditions. Additionally, this is the first attempt to apply quantitative Bayesian approach to address the effect of run-off inputs from melting glaciers on food sources and its spatial variation within the nearshore benthic community in Potter Cove. This certainly represents a step forward on the knowledge of Antarctic coastal ecosystem functioning in the face of ongoing environmental disturbances.

\section{CRediT authorship contribution statement}

Gastón Alurralde: Conceptualization, Methodology, Software, Formal analysis, Investigation. Verónica L. Fuentes: Conceptualization, Methodology, Investigation, Supervision. Marleen De Troch: Methodology, Supervision. Marcos Tatían: Conceptualization, Methodology, Supervision.

\section{Declaration of Competing Interest}

The authors declare that they have no known competing financial interests or personal relationships that could have appeared to influence the work reported in this paper.

\section{Acknowledgments}

This work was supported by the Total Foundation (ECLIPSE Project); Argentinean funds through PICT-Raíces 2011-1320 to IS, PICTO-DNA N ${ }^{\circ} 119$; the European Commision under the 7th Framework Programme through the Action - IMCONet (FP7 IRSES, action no. 319718); the American Museum of Natural History (Lerner-Gray Grant for Marine Research). It is a contribution to the Coastal Ecology Monitoring programme of Instituto Antártico Argentino/Dirección Nacional del Antártico in Carlini Station and the research program PACES II (topic 1, work package 5) of the Alfred Wegener Institute. GA received a PhD scholarship (CONICET) at the Universidad Nacional de Córdoba. We are grateful to the scientific, logistic and diving groups of Carlini Station-Dallmann Laboratory for their technical assistance during the Antarctic expeditions. In addition, to Oscar Gonzales, Alejandro Ullrich and Silvia Rodriguez from the Instituto Antártico Argentino (IAA). Finally, to Dr. Uxue Tilves, Dr. Melisa Acevedo and Dr. Jordi Grinyó for their help preparing and analysing samples.

\section{References}

Ahn, I.Y., 1993. Enhanced particle flux through the biodeposition by the Antarctic suspension-feeding bivalve Laternula elliptica in Marian Cove, King George Island. J. Exp. Mar. Biol. Ecol. 171, 75-90. https://doi.org/10.1016/0022-0981(93)90141-A.
Ahn, I.Y., Moon, H.W., Jeon, M., Kang, S.H., 2016. First record of massive blooming of benthic diatoms and their association with megabenthic filter feeders on the shallow seafloor of an Antarctic Fjord: Does glacier melting fuel the bloom? Ocean Science Journal 51 (2), 273-279. https://doi.org/10.1007/s12601-016-0023-y.

Altabet, M.A., 1988. Variations in nitrogen isotopic composition between sinking and suspended particles: implications for nitrogen cycling and particle transformation in the open-ocean. Deep-Sea Res. 35, 535-554. https://doi.org/10.1016/01980149(88)90130-6.

Alurralde, G., Campana, G.L., 2017. Gas-floating aggregates of Antarctic benthic diatoms. Matters Select 12-2017. https://sciencematters.io/articles/201703000008.

Alurralde, G., 2018. Enlace bento-pelágico en un ecosistema costero antártico afectado por el deshielo: una aproximación ecológica. Facultad de Ciencias Exactas, Físicas y Naturales. Universidad Nacional de Córdoba, Tesis Doctoral.

Alurralde, G., Fuentes, V.L., Olariaga, A., Orejas, C., Movilla, J., Maggioni, T., Schloss, I., Tatían, M., 2019. Role of suspension feeders in antarctic pelagic-benthic coupling: Trophic ecology and potential carbon sinks under climate change. Marine Environ. Res. https://doi.org/10.1016/j.marenvres.2019.104790.

Amsler, C.D., Iken, K., Mcclintock, J.B., Amsler, M.O., Peters, K.J., Hubbard, J.M., Furrow, F.B., Baker, B.J., 2005. Comprehensive evaluation of the palatability and chemical defenses of subtidal macroalgae from the Antarctic Peninsula. Mar. Ecol. Progr. Ser. 294, 141-159. https://doi.org/10.3354/meps294141.

Amsler, C.D., Mcclintock, J.B., Baker, B.J., 2012. Palatability of living and dead detached Antarctic macroalgae to consumers. Antarct. Sci. 24 (6), 589-590. https://doi.org/ 10.1017/S0954102012000624.

Andrade, C., Rios, C., Gerdes, D., Brey, T., 2016. Trophic structure of shallow-water benthic communities in the sub-Antarctic Strait of Magellan. Polar Biol 39. https:// doi.org/10.1007/s00300-016-1895-0.

Anderson, L.G., Macdonald, R., 2015. Observing the Arctic Ocean carbon cycle in a changing environment. Polar Res. 34, 2689. https://doi.org/10.3402/polar.v34 26891.

Anderson, M.J., 2001. A new method for non-parametric multivariate analysis of variance. Austral Ecol. 26, 32-46. https://doi.org/10.1111/j.1442-9993.2001.01070. pp. $\mathrm{x}$.

Aracena C, Lange CB, Iriarte JL, Rebolledo L, Pantoja S, 2011. Latitudinal patterns of export production recorded in surface sediments of the Chilean Patagonian fjords (41-551S) as a response to water column productivity. https://doi.org/10.1016/j.csr. 2010.08.008.

Arístegui, J., Duarte, C.M., Reche, I., Gómez-Pinchetti, J.L., 2014. Krill excretion boosts microbial activity in the Southern Ocean. PLoS ONE 9 (2). https://doi.org/10.1371/ journal.pone.0089391.

Barnes, D.K.A., Clarke, A., 1995. Seasonality of feeding activity in Antarctic suspension feeders. Polar Biol 15, 335-340. https://doi.org/10.1007/BF00238483.

Barnes, D.K.A., Sands, C.J., 2017. Functional group diversity is key to Southern Ocean benthic carbon pathways. PLoS ONE 12 (6), 14. https://doi.org/10.1371/journal. pone.0179735.

Bers, A.V., Momo, F., Schloss, I.R., Abele, D., 2013. Analysis of trends and sudden changes in long-term environmental data from King George Island (Antarctica): relationships between global climatic oscillations and local system response. Clim. Change 116, 789-803. https://doi.org/10.1007/s10584-012-0523-4.

Bosley, K.L., Wainright, S.C., 1999. Effects of preservatives and acidification on the stable isotope ratios $\left({ }^{15} \mathrm{~N}:{ }^{14} \mathrm{~N},{ }^{13} \mathrm{C}:{ }^{12} \mathrm{C}\right)$ of two species of marine animals. Canadian $\mathrm{J}$. Fisheries Aquatic Sci. 56, 2181-2185. https://doi.org/10.1139/f99-153.

Braeckman, U., Pasotti, F., Vázquez, S., Zacher, K., Hoffmann, R., Elvert, M., Marchant, H., Buckner, C., Quartino, M.L., Mac Cormack, W., Soetaert, K., Wenzhöfer, F., Vanreusel, A., 2019. Degradation of macroalgal detritus in shallow coastal Antarctic sediments. Limnol. Oceanogr. https://doi.org/10.1002/lno.11125.

Bunn, S.E., Loneragan, N.R., Kempster, M.A., 1995. Effects of acid washing on stable isotope ratios of $\mathrm{C}$ and $\mathrm{N}$ in penaeid shrimp and seagrass: implications for food- web studies using multiple stable isotopes. Limnol. Oceanogr. 40, 622e625. https://doi. org/10.4319/lo.1995.40.3.0622.

Campana, G.L., Zacher, K., Deregibus, D., Momo, F.R., Wiencke, C., Quartino, M.L., 2018. Succession of Antarctic benthic algae (Potter Cove, South Shetland Islands): structural patterns and glacial impact over a four-year period. Polar Biol. 41 (2), 377-396. https://doi.org/10.1007/s00300-017-2197-x.

Carabel, S., Godínez-Domínguez, E., Verísimo, P., Fernández, L., Freire, J., 2006. An assessment of sample processing methods for stable isotope analysis of marine food webs. J. Exp. Mar. Biol. Ecol. 336, 254e261. https://doi.org/10.1016/j.jembe.2006. 06.001 .

Choy, E.J., Park, H., Kim, J.-H., Ahn, I.-Y., Kang, C.-K., 2011. Isotopic shift for defining habitat exploitation by the Antarctic limpet Nacella concinna from rocky coastal habitats (Marian Cove, King George Island). Estuar. Coast. Shelf Sci. 92 (3), 339-346. https://doi.org/10.1016/j.ecss.2011.01.009.

Coma, R., Ribes, M., Gili, J.M., Hughes, R.N., 2001. The ultimate opportunists: consumers of seston. Mar. Ecol. Prog. Ser. 10 (219), 305-308. https://doi.org/10.3354/ meps219305.

Cook, A.J., Fox, A.J., Vaughan, D.G., Ferrigno, J.G., 2005. Retreating Glacier Fronts on the Antarctic Peninsula over the past Half-Century. Science 308, 541-544. https:// doi.org/10.1126/science.1104235.

Cook, A.J., Holland, P.R., Meredith, M.P., Murray, T., Luckman, A., Vaughan, D.G., 2016. Ocean forcing of glacier retreat in the western Antarctic Peninsula. Science 353 (6296), 283-286. https://doi.org/10.1126/science.aae0017.

Corbisier, T.N., Petti, M.A.V., Skowronski, R.S.P., Brito, T.A.S., 2004. Trophic relationships in the nearshore zone of Martel Inlet (King George Island, Antarctica): $\delta^{13} \mathrm{C}$ stable-isotope analysis. Polar Biol 27 (2), 75-82. https://doi.org/10.1007/s00300003-0567-z.

Deregibus, D., Quartino, M.L., Campana, G.L., Momo, F.R., Wiencke, C., Zacher, K., 2016. 
Photosynthetic light requirements and vertical distribution of macroalgae in newly ice-free areas in Potter Cove, South Shetland Islands. Antarctica. Polar Biol 39 (1), 153-166. https://doi.org/10.1007/s00300-015-1679-y.

Dame, R.F., Bushek, D., Prins, T., 2001. Benthic suspension feeders as determinants of ecosystem structure and function in shallow coastal waters. Ecological comparison of sedimentary shores. 11-37. https://doi.org/10.1007/978-3-642-56557-12.

Dubois, S., Blin, J.-L., Bouchaud, B., Lefebvre, S., 2007. Isotope trophic-step fractionation of suspension-feeding species: implications for food partitioning in coastal ecosystems. J. Exp. Mar. Biol. Ecol. 351, 121-128. https://doi.org/10.1016/j.jembe.2007 06.020 .

Dubois, S.F., Colombo, F., 2014. How picky can you be? Temporal variations in trophic niches of co-occurring suspension-feeding species. Food Webs 1, 1-9. https://doi. org/10.1016/j.fooweb.2014.07.001.

Dunton, K.H., 2001. $\mathrm{d}^{15} \mathrm{~N}$ and $\mathrm{d}^{13} \mathrm{C}$ Measurements of Antarctic Peninsula Fauna: Trophic Relationships and Assimilation of Benthic Seaweeds. Am. Zool. 41, 99-112. https:// doi.org/10.1093/icb/41.1.99.

Fisher, G., 1991. Stable carbon isotope ratios of plankton carbon and sinking organic matter from the Atlantic sector of the Southern Ocean. Mar. Chem. 35, 581-596. https://doi.org/10.1016/S0304-4203(09)90044-5.

Fisher, G., Wiencke, C., 1992. Stable carbon isotope composition, depth distribution and fate of macroalgae from the Antarctic peninsula region. Polar Biol. 12, 341-348. https://doi.org/10.1007/BF00243105.

Fuentes, V.L., 2006. Estudio de la Comunidad Zooplanctónica de Caleta Potter y Bahía Guardia Nacional (Isla 25 de Mayo): su Rol en la Dinámica del Carbono en Zonas Costeras Antárticas. Universidad de Buenos Aires, Tesis Doctoral, pp. 249.

Fuentes, V., Alurralde, G., Meyer, B., Aguirre, G.E., Canepa, A., Wölfl, A.C., Hass, C.H., Williams, G.N., Schloss, I.R., 2016. Glacial melting: an overlooked threat to Antarctic krill. Sci. Rep. 27234. https://doi.org/10.1038/srep27234.

Gambi, M.C., Castelli, A., Guizzardi, M., 1997. Polychaete populations of the shallow soft bottoms off Terra Nova Bay (Ross Sea, Antarctica): distribution, diversity and biomass. Polar Biol 17, 199-210. https://doi.org/10.1007/s003000050123.

Garcia, M.D., Hoffmeyer, M.S., Abbate, M.C.L., de Cao, M.S.B., Pettigrosso, R.E., Almandoz, G.O., Hernando, M.P., Schloss, I.R., 2016. Micro- and mesozooplankton responses during two contrasting summers in a coastal Antarctic environment. Polar Biol 1-15. https://doi.org/10.1007/s00300-015-1678-z.

Gardner, J.P.A., 2000. Where are the mussels on Cook Strait (New Zealand) shores? Low seston quality as a possible factor limiting multi-species distributions. Mar Ecol Prog Ser 194, 123-132. https://doi.org/10.3354/meps194123.

Gillies, C.L.L., Stark, J.S.S., Johnstone, G.J.J., Smith, S.D.A., 2012. Carbon flow and trophic structure of an Antarctic coastal benthic community as determined by $\delta^{13} \mathrm{C}$ and $\delta^{15}$ N. Estuar. Coast. Shelf Sci. 97, 44-57. https://doi.org/10.1016/j.ecss.2011. 11.003.

Gillies, C., Stark, J., Johnstone, G., Smith, S., 2013. Establishing a food web model for coastal Antarctic benthic communities: a case study from the Vestfold Hills. Mar. Ecol. Prog. Ser. 478, 27-41. https://doi.org/10.3354/meps10214.

Guest, M.A., Connolly, R.M., Loneragan, N.R., 2004. Carbon movement and assimilation by invertebrates in estuarine habitats at a scale of metres. Mar. Ecol. Prog. Ser. 278, 27-34. https://doi.org/10.3354/meps278027.

Gutt, J., Bertler, N., Bracegirdle, T.J., Buschmann, A., Comiso, J., Hosie, G., Isla, E., Schloss, I.R., Smith, C.R., Tournadre, J., Xavier, J.C., 2015. The Southern Ocean ecosystem under multiple climate change stresses-an integrated circumpolar assessment. Glob. Change Biol. 21 (4), 1434-1453. https://doi.org/10.1111/gcb.12794.

Ha, S.Y., Ahn, I.Y., Moon, H.W., Choi, B., Shin, K.H., 2019. Tight trophic association between benthic diatom blooms and shallow-water megabenthic communities in a rapidly deglaciated Antarctic fjord. Estuar. Coast Shelf Sci. 218, 258-267. https:// doi.org/10.1016/j.ecss.2018.12.020.

Hammer, Ø., Harper, D.A., Ryan, P.D., 2001. PAST: Paleontological statistics software package for education and data analysis. Palaeontol. Electronica 4 (1), 9.

Hoffmann, R., Al-Handal, A.Y., Wulff, A., Deregibus, D., Quartino, M.L., Wenzhöfer, F., Braeckman, U., 2019. Implications of glacial melt-related processes on the potential primary production of a microphytobenthic community in Potter Cove (Antarctica). Front. Mar. Sci. 6, 655. https://doi.org/10.3389/fmars.2019.00655.

Hoffmann, R., Pasotti, F., Vázquez, S., Lefaible, N., Torstensson, A., MacCormack, W., Wenzhöfer, F., Braeckman, U., 2018. Spatial variability of biogeochemistry in shallow coastal benthic communities of Potter Cove (Antarctica) and the impact of a melting glacier. PLoS One 13 (12), e0207917. https://doi.org/10.1371/journal.pone. 0207917.

Hyndes, G.A., Hanson, C.E., Vanderklift, M.A., 2013. The magnitude of spatial and temporal variation in $\delta^{15} \mathrm{~N}$ and $\delta^{13} \mathrm{C}$ differs between taxonomic groups: implications for food web studies. Estuar Coast Shelf Sci 119, 176-187. https://doi.org/10.1016/j. ecss.2012.12.015.

Jacob, U., Mintenbeck, K., Brey, T., Knust, R., Beyer, K., 2005. Stable isotope food web studies: a case for standardized sample treatment. Mar. Ecol. Prog. Ser. 287, 251-253. http://www.jstor.org/stable/24869029.

Jansen, J., Hill, N.A., Dunstan, P.K., Mckinlay, J., Sumner, M.D., Post, A.L., Eléaume, M.P., Armand, L.K., Warnock, J.P., Galton-Fenzi, B.K., Johnson, C.R., 2018a Abundance and richness of key Antarctic seafloor fauna correlates with modelled food availability. Nat. Ecol. Evol. 2, 71-80. https://doi.org/10.1038/s41559-0170392-3.

Jansen, J., Hill, N.A., Dunstan, P.K., Cougnon, E.A., Galton-fenzi, B.K., Johnson, C.R., 2018b. Mapping Antarctic suspension feeder abundances and seafloor food-availability, and modeling their change after a major glacier calving. Front. Ecol. Evol. 6 (94), 1-11. https://doi.org/10.3389/fevo.2018.00094.

Jerosch, K., Pehlke, H., Monien, P., Scharf, F., Weber, L., Kuhn, G., Braun, M.H., Abele, D., 2018. Benthic meltwater fjord habitats formed by rapid glacier recession on King George Island, Antarctica. Philosophical Transactions of the Royal Society A:
Mathematical, Physical and Engineering Sciences. 376 (2122), 20170178. https:// doi.org/10.1098/rsta.2017.0178.

Jia, Z., Swadling, K.M., Meiners, K.M., Kawaguchi, S., Virtue, P., 2016. The zooplankton food web under East Antarctic pack ice - A stable isotope study. Deep Sea Res. II Top. Stud. Oceanogr. 131, 189-202. https://doi.org/10.1016/j.dsr2.2015.10.010.

Kapsenberg, L., Kelley, A.L., Shaw, E.C., Martz, T.R., Hofmann, G.E., 2015. Near-shore Antarctic $\mathrm{pH}$ variability has implications for the design of ocean acidification experiments. Sci. Rep. 1-10. https://doi.org/10.1038/srep09638.

Kennedy, P., Kennedy, H., Papadimitriou, S., 2005. The effect of acidification on the determination of organic carbon, total nitrogen and their stable isotopic composition in algae and marine sediment. Rapid Commun. Mass Spectrom. 19, 1063-1068. https://doi.org/10.1002/rcm.1889.

Khim, B.K., Kim, D., Shin, H.C., Kim, D.Y., 2005. Stable Carbon and Nitrogen Isotopes of Sinking Particles in the Eastern Bransfield Strait (Antarctica). Ocean Science Journal 176 (3), 167-176. https://doi.org/10.1007/BF03022610.

Klöser, H., Quartino, M.L., Wiencke, C., 1996. Distribution of macroalgae and macroalgal communities in gradients of physical conditions in Potter Cove, King George Island Antarctica Hydrobiologia. 333, 1. https://doi.org/10.1007/BF00020959.

Koike, I., Holm-Hansen, O., Biggs, D.C., 1986. Inorganic nitrogen metabolism by Antarctic phytoplankton with special reference to ammonium cycling. Mar. Ecol. Prog. Ser. 30 (2-3), 105-116. https://www.jstor.org/stable/24817543.

Kröger, K., Rowden, A.A., 2008. Polychaete assemblages of the northwestern Ross Sea shelf : worming out the environmental drivers of Antarctic macrobenthic assemblage composition. Polar Biol 1 (31), 971-989. https://doi.org/10.1007/s00300-0080437-9.

Lagger, C., Nime, M., Torre, L., Servetto, N., Tatián, M., Sahade, R., 2018. Climate change, glacier retreat and a new ice-free Island offer new insights on antarctic benthic responses. Ecography 0-2, 7491. https://doi.org/10.1111/ecog.03018.

Lagger, C., Servetto, N., Torre, L., Sahade, R., 2017. Benthic colonization in newly ice-free soft-bottom areas in an Antarctic fjord. PLoS ONE 12 (11), e0186756. https://doi. org/10.1371/journal.pone.0186756.

Lawton, J.H., 1994. What do species do in ecosystems? Oikos 71 (3), 367-374. https:// doi.org/10.2307/3545824.

Logan, J.M., Jardine, T.D., Miller, T.J., Bunn, S.E., Cunjak, R.A., Lutcavage, M.E., 2008. Lipid corrections in carbon and nitrogen stable isotope analyses: comparison of chemical extraction and modelling methods. J. Anim. Ecol. 77, 838-846. https://doi. org/10.1111/j.1365-2656.2008.01394.x.

McCutchan Jr, J.H., Lewis Jr, W.M., Kendall, C., McGrath, C.C., 2003. Variation in trophic shift for stable isotope ratios of carbon, nitrogen, and sulfur. Oikos 102, 378-390. https://doi.org/10.1034/j.1600-0706.2003.12098.x.

Meredith, M.P., Falk, U., Valeria, A., Mackensen, A., Schloss, I.R., Barlett, E.R., Jerosch, K., Silva Busso, A., Abele, D., 2018. Anatomy of a glacial meltwater discharge event in an Antarctic cove. Phil. Trans. R. Soc. A 376, 20170163. https://doi.org/10.1098/ rsta.2017.0163.

Mincks, S.L., Smith, C.R., Jeffreys, R.M., Sumida, P.Y.G., 2008. Trophic structure on the West Antarctic Peninsula shelf: Detritivory and benthic inertia revealed by $\delta^{13} \mathrm{C}$ and $\delta^{15} \mathrm{~N}$ analysis. Deep Sea Res. Part II 55 (22-23), 2502-2514. https://doi.org/10. 1016/j.dsr2.2008.06.009.

Mintenbeck, K., Brey, T., Jacob, U., Knust, R., Struck, U., 2008. How to account for the lipid effect on carbon stable isotope ratio $\left(\delta^{13} \mathrm{C}\right)$ : sample treatment effects and model bias. J. Fish Biol. 72, 815-830. https://doi.org/10.1111/j.1095-8649.2007.01754.x.

Monien, D., Monien, P., Brünjes, R., Widmer, T., Kappenberg, A., Busso, A.A.S., Schnetger, B., Brumsack, H., 2017. Meltwater as a source of potentially bioavailable iron to Antarctica waters. Antarct. Sci. 15, 1-15. https://doi.org/10.1017/ S095410201600064X.

Montoya, J.P., McCarthy, J.J., 1995. Isotopic fractionation during nitrate uptake by phytoplankton grown in continuous culture. J. Plankton Res. 17 (3), 439-464. https://doi.org/10.1093/plankt/17.3.439.

Morales, L.V., Granger, J., Chang, B.X., Prokopenko, M.G., Plessen, B., Gradinger, R., Sigman, D.M., 2014. Elevated ${ }^{15} \mathrm{~N} /{ }^{14} \mathrm{~N}$ in particulate organic matter, zooplankton, and diatom frustule-bound nitrogen in the ice-covered water column of the Bering Sea eastern shelf. Deep Sea Res. Part II 109, 100-111. https://doi.org/10.1016/j. dsr2.2014.05.008.

Morata, N., Seuthe, L., 2014. Importance of bacteria and protozooplankton for faecal pellet degradation. Oceanologia 56 (3), 565-581. https://doi.org/10.5697/oc.56-3. 565

Nedwell, D.B., Walker, T.R., 1995. Sediment-water fluxes of nutrients in an Antarctic coastal environment: influence of bioturbation. Polar Biol. 15 (1), 57-64. https://doi. org /10.1007/BF00236125.

Norkko, A., Thrush, S.F., Cummings, V.J., Gibbs, M.M., Andrew, N.L., Norkko, J., Schwarz, A.M., 2007. Trophic structure of coastal Antarctic food webs associated with changes in sea ice and food supply. Ecology 88 11, 2810e2820. https://doi.org/ 10.1890/06-1396.1.

Parnell, A.C., 2016. simmr: A stable isotope mixing model. R package version 3.

Parnell, A., Inger, R., Bearhop, S., Jackson, A.L., 2010. Source partitioning using stable isotopes: coping with too much variation. PlosOne 5 (3), e9672. https://doi.org/10. 1371/journal.pone.0009672.

Pasotti, F., Saravia, L.A., De Troch, M., Tarantelli, M.S., Sahade, R., Vanreusel, A., 2015 Benthic trophic interactions in an Antarctic shallow water ecosystem affected by recent glacier retreat. PLoS ONE 10 (11), 1-26. https://doi.org/10.1371/journal. pone.0141742.

Petersen, J.K., 2007. Ascidian suspension feeding. J. Exp. Mar. Biol. Ecol. 342 (1), 127-137. https://doi.org/10.1016/j.jembe.2006.10.023.

Pinnegar, J.K., Polunin, N.V.C., 1999. Differential fractionation of $\delta^{13} \mathrm{C}$ and $\delta^{15} \mathrm{~N}$ among fish tissues: implications for the study of trophic relationships. Funct Ecol 13, 225-231. https://doi.org/10.1046/j.1365-2435.1999.00301.x. 
Post, D.M., 2002. Using stable isotopes to estimate trophic position: models, methods, and assumptions. Ecology 83 (3), 703-718. https://doi.org/10.1890/0012-9658(2002) 083[0703:USITET]2.0.CO;2.

Post, D.M., Layman, C.A., Arrington, D.A., Takimoto, G., Quattrochi, J., Montanã, C.G., 2007. Getting to the fat of the matter: models, methods and assumptions for dealing with lipids in stable isotope analyses. Oecol 152, 179e189. https://doi.org/10.1007/ s00442-006-0630-x.

Probyn, T.A., Painting, S.J., 1985. Nitrogen uptake by size-fractionated phytoplankton populations in Antarctic surface waters. Limnol. Oceangr. 30, 1327-1332. https:// doi.org/10.4319/1o.1985.30.6.1327.

Quartino, M.L., Boraso de Zaixso, A.L., 2008. Summer macroalgal biomass in Potter Cove, South Shetland Islands, Antarctica: its production and flux to the ecosystem. Polar Biol 31, 281-294. https://doi.org/10.1007/s00300-007-0356-1.

Quartino, M.L., Deregibus, D., Campana, G.L., Latorre, G.E.J., Momo, F.R., 2013. Evidence of macroalgal colonization on newly ice-free areas following glacial retreat in Potter Cove (South Shetland Islands). Antarctica. PloS One 8 (3), e58223. https:// doi.org/10.1371/journal.pone.0058223.

Quartino, M.L., Vazquez, S.C., Latorre, G.E.J., Mac Cormack, W.P., 2015. Possible role of bacteria in the degradation of macroalgae Desmarestia anceps Montagne (Phaeophyceae) in Antarctic marine waters. Rev. Argent. Microbiol. 47 (3), 274-276. https://doi.org/10.1016/j.ram.2015.04.003.

Quartino, M.L., Zaixso, H.E., Zaixso, A.L.B., 2005. Biological and environmental characterization of marine macroalgal assemblages in Potter Cove, South Shetland Islands, Antarctica. Bot. Mar. 48, 187-197. https://doi.org/10.1515/BOT.2005.029.

Rau, G.H., Mearns, A.J., Young, D.R., Olson, R.J., Schafer, H.A., Kaplan, I.R., 1983. Animal 13C/12C correlates with trophic level in pelagic food webs. Ecology 64 1314e1318. https://doi.org/10.2307/1937843.

Riisgård, H.U., Larsen, P.S., 2010. Particle capture mechanisms in suspension-feeding invertebrates. Mar Ecol Prog Ser 418, 255-293. https://doi.org/10.3354/ meps08755.

Roese M, Drabble M, 1998. Wind driven circulation in Potter Cove. In Wiencke C, Ferreyra GA, Arntz W, Rinaldi C, (eds) The Potter Cove coastal ecosystem, Antarctica. Bremerhaven: Alfred Wegener Institute for Polar and Marine Research and Buenos Aires: Instituto Antartico Argentino, 40-46.

Rossi S, Coppari M, Viladrich N, 2015. Benthic-Pelagic Coupling: New Perspectives in the Animal Forests. In: Rossi S, Bramanti L, Gori A, Covadonga O (eds) Marine Animal Forests: The Ecology of Benthic Biodiversity Hotspots. Springer International Publishing, Cham, https://doi.org/10.1007/978-3-319-17001-5.

Rückamp, M., Braun, M., Suckro, S., Blindow, N., 2011. Observed glacial changes on the King George Island ice cap, Antarctica, in the last decade. Global Planet Change. 79, 99-109. https://doi.org/10.1016/j.gloplacha.2011.06.009.

Sahade, R., Lagger, C., Torre, L., Momo, F., Monien, P., Schloss, I., Barnes, D.K.A., Servetto, N., Tarantelli, S., Tatián, M., Zamboni, N., Abele, D., 2015. Climate change and glacier retreat drive shifts in an Antarctic benthic ecosystem. Sci. Adv. 1 (10), e1500050. https://doi.org/10.1126/sciadv.1500050.

Schaal, G., Riera, P., Leroux, C., 2008. Trophic coupling between two adjacent benthic food webs within a man-made intertidal area: a stable isotopes evidence. Estuar. Coast. Shelf Sci. 77, 523-534. https://doi.org/10.1016/j.ecss.2007.10.008.

Schaal, G., Riera, P., Leroux, C., 2011. Microscale variations of food web functioning within a rocky shore invertebrate community. Mar Biol. 158, 623-630. https://doi org/10.1007/s00227-010-1586-2.

Schloss, I.R., Abele, D., Moreau, S., Demers, S., Bers, V., González, O., Ferreyra, G.A., 2012. Response of phytoplankton dynamics to 19-year (1991-2009) climate trends in Potter Cove (Antarctica). J Mar Syst. 92, 53-66. https://doi.org/10.1016/j.jmarsys. 2011.10.006.

Schloss, I.R., Ferreyra, G.A., Ruiz-Pino, D., 2002. Phytoplankton biomass in Antarctic shelf zones: A conceptual model based on Potter Cove, King George Island. J. Mar. Syst. 36 (3-4), 129-143. https://doi.org/10.1016/S0924-7963(02)00183-5.

Schloss, I.R., Klöser, H., Ferreyra, G.A., Curtosi, A., Mercuri, G., Pinola, E., 1997. Factors governing phytoplankton and particulate matter variation in Potter Cove, King George Island, Antarctica. In: Battaglia, B., Valencia, J., Walton, D.W.H. (Eds.), Antarctic communities. Cambridge University Press, London, pp. 135-214.

Schloss, I.R., Wasilowska, A., Dumont, D., Almandoz, G.O., Hernando, M.P., Michaud-
Tremblay, C.A., Saravia, L., Rzepecki, M., Monien, P., Monien, D., Kopczynska, E.E., Ferreyra, G.A., 2014. On the phytoplankton bloom in coastal waters of southern King George Island (Antarctica) in January 2010: An exceptional feature? Limnol Oceanogr. 59 (1), 195-210. https://doi.org/10.1594/PANGAEA.754676.

Servetto, N., Rossi, S., Fuentes, V., Alurralde, G., Lagger, C., Sahade, R., 2017. Seasonal trophic ecology of the dominant Antarctic coral Malacobelemnon daytoni (Octocorallia, Pennatulacea, Kophobelemnidae). Marine Environmental Research 130, 264-274. https://doi.org/10.1016/j.marenvres.2017.08.003.

Smith Jr., W.O., Nelson, D.M., 1990. Phytoplankton growth and new production in the Weddell Sea marginal ice zone in the austral spring and autumn. Limnol. Oceanogr. 35, 809-821. https://doi.org/10.4319/lo.1990.35.4.0809.

Smith, R., Bianchi, S.T., Allison, M., Savage, C., Galy, V., 2015. High rates of organic carbon burial in fjord sediments globally. Nature Geosciences 8, 450-454. https:// doi.org/10.1038/ngeo2421.

Spence, P., Holmes, R.M., Hogg, A.M., Griies, S.M., Stewart, K.D., England, M.H., 2017. Localized rapid warming of West Antarctic subsurface waters by remote winds. https://doi.org/10.1038/NCLIMATE3335.

Tatián, M., Sahade, R., Mercuri, G., Fuentes, V.L., Antacli, J.C., Stellfeldt, A., Esnal, G.B., 2008. Feeding ecology of benthic filter-feeders at Potter Cove, an Antarctic coastal ecosystem. Polar Biol. 31, 509-517. https://doi.org/10.1007/s00300-007-0379-7.

Tortell PD, Asher EC, Ducklow HW, Goldman JAL, Dacey JWH, Grzymski JJ, Young JN, Kranz SA, Bernard KS, Morel FMM, 2014. Metabolic balance of coastal Antarctic waters revealed by autonomous pCO2 and $\triangle \mathrm{O} 2 / \mathrm{Ar}$ measurements. Geophys. Res. Lett. 41 (19). http://dx.doi.org/10.1002/2014GL061266.

Trull, T.W., Davies, D.M., Dehairs, F., Cavagna, A.-J., Lasbleiz, M., Laurenceau, E.C., d'Ovidio, F., Planchon, F., Leblanc, K., Quéguiner, B., Blain, S., 2014. Chemometric perspectives on plankton community responses to natural iron fertilization over and downstream of the Kerguelen Plateau in the Southern Ocean. Biogeosciences Discuss. 11, 13841-13903. https://doi.org/10.5194/bgd?11?13841?2014.

Tu, K.L., Blanchard, A.L., Iken, K., Horstmann-Dehn, L., 2015. Small-scale spatial variability in benthic food webs in the northeastern Chukchi Sea. Mar. Ecol. Prog. Ser. 528, 19-37. https://doi.org/10.3354/meps11216.

Vaughan, D.G., 2006. Recent trends in melting conditions on the Antarctic Peninsula and their implications for ice-sheet mass balance and sea level. Arct. Antarct. Alp. Res. 38 (1), 147-152. https://doi.org/10.1657/1523-0430(2006)038[0147:RTIMCO]2.0. $\mathrm{CO} ; 2$.

Vaughan, D.G., Marchall, G.J., Connolley, W.M., Parkinson, C., Mulvaney, R., Hodgson, D.A., King, J.C., Pudsey, C.J., Turner, J., 2003. Recent rapid regional climate warming on the Antarctic Peninsula. Clim. Change 60, 243-274. https://doi.org/10. 1023/A:1026021217991.

Wada, E., Terazaki, M., KAbaya Y, Nemoto T, 1987. ${ }^{15} \mathrm{~N}$ and ${ }^{13} \mathrm{C}$ abundances in the Antarctic Ocean with emphasis on the biogeochemical structure of the food web. Deep-Sea Res. 34, 829-841. https://doi.org/10.1016/0198-0149(87)90039-2.

Wassmann, P., Reigstad, M., Haug, T., Rudels, B., Carroll, M.L., Hop, H., 2006. Food webs and carbon flux in the Barents Sea. Prog. Oceanogr. 71 (2), 232-248. https://doi.org/ 10.1016/j.pocean.2006.10.003.

Wölfl, A.C., Lim, C.H., Hass, H.C., Lindhorst, S., Tosonotto, G., Lettmann, K.A., Kuhn, G., Wolff, J.O., Abele, D., 2014. Distribution and characteristics of marine habitats in a subpolar bay based on hydroacoustics and bed shear stress estimates-Potter Cove, King George Island. Antarctica. Geo-Marine Letters. 34, 435-446. https://doi.org/10 1007/s00367-014-0375-1.

Zaborska, A., Włodarska-Kowalczuk, M., Legeżyńska, J., Jankowska, E., Winogradow, A., Deja, K., 2016. Sedimentary organic matter sources, benthic consumption and burial in west Spitsbergen fjords - Signs of maturing of Arctic fjordic systems? J. Mar. Syst. https://doi.org/10.1016/j.jmarsys.2016.11.005.

Zajączkowski, M., Nygård, H., Hegseth, E.N., Berge, J., 2010. Vertical flux of particulate matter in an Arctic fjord: the case of lack of the sea-ice cover in Adventfjorden 2006-2007. Polar Biol. 33, 223-239. https://doi.org/10.1007/s00300-009-0699-x.

Zenteno, L., Cárdenas, L., Valdivia, N., Gómez, I., Höfer, J., Garrido, I., Pardo, L.M., 2019. Unraveling the multiple bottom-up supplies of an Antarctic nearshore benthic community. Prog. Oceanogr. 174 (June), 55-63. https://doi.org/10.1016/j.pocean.2018. 10.016 . 